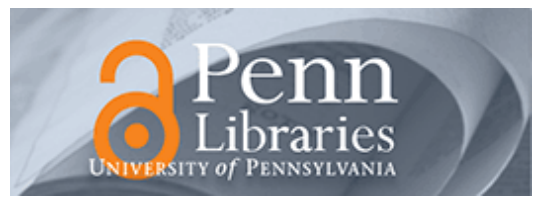

University of Pennsylvania

ScholarlyCommons

Management Papers

Wharton Faculty Research

$10-2016$

\title{
Dual Directors and the Governance of Corporate Spinoffs
}

Emilie R. Feldman

University of Pennsylvania

Follow this and additional works at: https://repository.upenn.edu/mgmt_papers

Part of the Business Administration, Management, and Operations Commons, Business and Corporate Communications Commons, Business Intelligence Commons, Corporate Finance Commons, Management Information Systems Commons, Management Sciences and Quantitative Methods Commons, Organizational Behavior and Theory Commons, and the Strategic Management Policy Commons

\section{Recommended Citation}

Feldman, E. R. (2016). Dual Directors and the Governance of Corporate Spinoffs. Academy of Management Journal, 59 (5), 1754-1776. http://dx.doi.org/10.5465/amj.2013.0552

This paper is posted at ScholarlyCommons. https://repository.upenn.edu/mgmt_papers/333

For more information, please contact repository@pobox.upenn.edu. 


\title{
Dual Directors and the Governance of Corporate Spinoffs
}

\begin{abstract}
This paper investigates how "dual directors" enable firms that undertake corporate spinoffs to manage their post-spinoff relationships with the firms they divest, as well as the performance implications of dual directors serving simultaneously on these companies' boards. While the presence of dual directors is positively associated with the average stock market returns of parent and spinoff firms, their presence is also increasingly positively associated with parent firm performance, but increasingly negatively associated with spinoff firm performance as the share of sales a spinoff firm makes to its parent firm rises. These findings show that, while dual directors give a parent firm power over its spinoff firm, dual directors only exercise that power at the spinoff firm's expense when that company is highly dependent on its parent firm.
\end{abstract}

\section{Keywords}

dual directors, corporate spinoffs, governance, power, transaction cost economics, resource dependence theory

\section{Disciplines}

Business Administration, Management, and Operations | Business and Corporate Communications | Business Intelligence | Corporate Finance | Management Information Systems | Management Sciences and Quantitative Methods | Organizational Behavior and Theory | Strategic Management Policy 


\title{
Dual Directors and the Governance of Corporate Spinoffs*
}

\author{
Emilie R. Feldman ${ }^{\dagger}$
}

\begin{abstract}
This paper investigates how "dual directors" enable firms that undertake corporate spinoffs to manage their post-spinoff relationships with the firms they divest, as well as the performance implications of dual directors serving simultaneously on these companies' boards. While the presence of dual directors is positively associated with the average stock market returns of parent and spinoff firms, their presence is increasingly positively associated with parent firm performance but increasingly negatively associated with spinoff firm performance as the share of sales a spinoff firm makes to its parent firm rises. These findings show that while dual directors give a parent firm power over its spinoff firm, dual directors only exercise that power at the spinoff firm's expense when that company is highly dependent on its parent firm.
\end{abstract}

Keywords: dual directors, corporate spinoffs, governance, power, transaction cost economics, resource dependence theory

\section{Forthcoming, Academy of Management Journal}

${ }^{*}$ I am very grateful to Academy of Management Journal Associate Editor Kyle Mayer and three anonymous reviewers for their helpful comments throughout the review process. I also thank Raffi Amit, Don Bergh, Matthew Bidwell, Olivier Chatain, Adam Cobb, Kira Fabrizio, Martine Haas, Deepak Hegde, Vit Henisz, Zeke Hernandez, Aseem Kaul, Dan Levinthal, Ethan Mollick, Evan Rawley, Jeff Reuer, Arkadiy Sakhartov, Harbir Singh, Catherine Thomas, Natalya Vinokurova, and Tyler Wry for their suggestions on earlier drafts of this paper. I appreciate the comments of seminar participants at INSEAD, HEC-Paris, Boston University, Columbia University, the 2014 NYU Economics of Strategy Workshop, the 2014 Atlanta Competitive Advantage Conference, the 2013 Strategic Management Society Annual Meeting, the 2013 Academy of Management Annual Meeting, the 2012 Strategy Research Forum Annual Meeting, the 2012 Academy of Management BPS Division New Faculty Consortium, and the 2012 Duke Strategy MiniConference. I thank Kelsey Brongo, Michael Buzinover, Robbie Grove, Thomas Ippolito, Jason Rudin, Rebecca Schmierer, Serena Zhou, and especially Levi Abramson and Jeff Wen for their assistance in collecting and coding the data from the Securities and Exchange Commission filings. I gratefully acknowledge the financial support of the Mack Center for Technological Innovation, the Center for Leadership and Change Management, and the PURM program at the University of Pennsylvania. Any errors are my own.

†The Wharton School, University of Pennsylvania, feldmane@wharton.upenn.edu 


\section{INTRODUCTION}

Corporate spinoffs, a type of divestiture in which a "parent firm" distributes shares in one of its business units pro-rata to its shareholders, have come to constitute an increasingly prevalent form of corporate strategic activity in recent times (Surowiecki, 2014; Sorkin, 2014), concomitantly garnering more and more attention in the academic literature (Brauer, 2006; Lee \& Madhavan, 2010). Much existing research in this domain focuses on the performance implications of these deals (along with those of divestitures more generally) for parent firms (Markides, 1992, 1995; Bergh, 1995; Comment \& Jarrell, 1995; Daley, Mehrotra, \& Sivakumar, 1997; Desai \& Jain, 1999), as well as the choices of which businesses to divest and when to divest them (Zuckerman, 2000; Gilson et al., 2001; Capron, Mitchell, \& Swaminathan, 2001; Berry, 2010; Kaul, 2012; Feldman, 2014). A distinctive characteristic of corporate spinoffs is that, in contrast to asset sales (another prevalent form of divestiture in which one firm sells a business unit to another company), spinoffs result in the creation of independent, publicly-traded companies, called "spinoff firms." A growing body of research has begun to explore the functioning and performance of these new companies as well (Seward \& Walsh, 1996; Corley \& Gioia, 2004; Tripsas, 2009; Semadeni \& Cannella, 2011; Moschieri, 2011).

As becomes evident from the above discussion, extant research about spinoffs has, for the most part, treated parent and spinoff firms as being independent of one another once their spinoffs are complete. However, this treatment may be questionable because the parent and spinoff firms that are involved in these deals emerge from the same entity, meaning that certain relationships between those companies might exist post-spinoff. This suggests that parent firms might need to put mechanisms in place that give them the power to manage their post-spinoff relationships with the spinoff firms they divest. A unique feature of spinoffsthe legal right of parent firms to appoint their own directors to serve simultaneously on their spinoff firms' boards - enables parent firms to do just this.

Accordingly, this study seeks to address two interrelated research questions: how do these "dual directors" enable parent firms to manage their post-spinoff relationships with 
their spinoff firms, and what implications does the presence of dual directors have for both parent and spinoff firm performance? To answer these questions, I build off of the insight that dual directors give a parent firm power over its spinoff firm, creating the potential for a conflict of interests to emerge by putting dual directors in a position to benefit the parent firm at the spinoff firm's expense. This raises the issue of when this conflict of interests would be expected to manifest itself. I draw on transaction cost economics (TCE) and resource dependence theory (RDT) to determine when this is and is not likely to occur.

Analogously to Reuer (2001), I use TCE to conceptualize spinoffs as a shift from hierarchy to market, since these deals disintegrate a subsidiary from within a diversified firm. Because the parent firm has lost the control of the spun-off subsidiary that internalization previously afforded it, a spinoff necessitates the implementation of a governance mechanism that gives the parent firm the power to manage its relationship with its spinoff firm (Shervani, Frazier, \& Challagalla, 2007). While dual directors give the parent firm this power, it is not, ex ante, obvious when dual directors will exercise that power on behalf of the parent firm in a way that is costly to the spinoff firm. I argue that this will not occur in most situations, since parent firms are usually stronger than their spinoff firms to begin with. Instead, following this TCE-based line of reasoning, I explain that in most cases, dual directors would be expected to exercise power on behalf of the parent firm by enabling it to coordinate its interorganizational relationship with the spinoff firm it has divested (Gulati \& Singh, 1998), with neutral or even favorable implications for that spinoff firm. However, I then invoke RDT to argue that one circumstance in which dual directors would be expected to exercise power at the expense of a spinoff firm is when that firm makes a large share of its sales to its parent firm (Casciaro \& Piskorski, 2005; Gulati \& Sytch, 2007). In these situations, the spinoff firm's dependence on its parent firm gives dual directors both the motivation and the ability to exercise power on behalf of the parent firm in a way that is costly to its spinoff firm.

Consistent with these arguments, I establish that the presence of one or more dual directors is positively associated with the average stock market returns of parent and spinoff 
firm pairs. However, I also find evidence that as the share of sales a spinoff firm makes to its parent firm rises, the presence of one or more dual directors becomes increasingly positively associated with parent firm performance, but increasingly negatively associated with spinoff firm performance. These results are derived using empirical methodologies that account for the effects of unobserved, deal-specific heterogeneity and non-random selection in the parent-spinoff firm pairs in which dual directors are appointed.

The core conceptual insight to emerge from this study is that dual directors give parent firms power over their spinoff firms, but the degree to which a spinoff firm is dependent on its parent firm determines when dual directors will actually exercise that power at the spinoff firm's expense. On a theoretical level, this suggests that while TCE illustrates how the implementation of a governance mechanism might give one firm power over another, the introduction of RDT sheds light on when and how that firm might exercise its power in a manner that is costly to its counterparty. On a practical level, moreover, the finding that the presence of dual directors is value-creating on average, despite its divergent distributional implications when the spinoff firm's sales dependence on its parent firm is high, raises the ethical issue that the redistributive role that dual directors appear to play in certain situations may be masked by the coordinative function they serve in most other circumstances. In sum, this paper offers key insights into a novel area of inquiry, the governance of corporate spinoffs, with significant implications for TCE and RDT as well.

\section{THEORY AND HYPOTHESES}

\section{The Governance of Corporate Spinoffs}

Parent firms face a significant challenge when undertaking spinoffs. On the one hand, parent firms undertake these deals for myriad reasons, such as redeploying resources (Chang,

1996; Capron et al., 2001; Helfat \& Eisenhardt, 2004), improving the focus of managerial attention (Markides, 1992, 1995; Daley et al., 1997), clarifying shareholder and analyst 
perceptions (Zuckerman, 2000; Gilson et al., 2001; Bergh, Johnson, \& DeWitt, 2008), and removing underperforming business units (Desai \& Jain, 1999; Hayward \& Shimizu, 2006; Shimizu, 2007). Whatever the precise motivation(s) for spinning off a business might be, the decision to undertake that spinoff is likely to be an economically rational one, suggesting that the parent firm believes that the value of divesting that subsidiary exceeds the value of keeping it integrated within its operations. This intuition is reinforced by numerous empirical studies documenting a positive association between divestitures (including spinoffs in particular) and firm value (e.g., Bergh, 1995; Comment \& Jarrell, 1995; Daley et al. 1997; Desai and Jain, 1999; Feldman, 2014).

On the other hand, an important characteristic of spinoffs is that existing relationships between parent and spinoff firms do not simply terminate upon the completion of these deals. For one thing, the divestiture process is complex, at least temporarily necessitating the continuation of interactions between the parent and spinoff firms as they separate their operations (Gilson, 2000; Feldman, Gilson, \& Villalonga, 2014). For another, certain economic relationships that existed between a parent firm and its former subsidiary might persist post-spinoff. A parent firm can maintain up to a $20 \%$ ownership stake in its spinoff firm without threatening the tax-free status of that deal, for example, or the two companies could continue to share common customers or suppliers, or even remain involved in exchange relationships with one another (Miles \& Woolridge, 1999; Semadeni \& Cannella, 2011). To the extent that the parent and spinoff firms do continue interacting, the manner in which the value resulting from that relationship will be distributed between those two firms may not be well-defined, a priori. These ideas are all underscored by the description provided by Juan Ramón Alaix, the CEO of Zoetis, about his company's relationship with Pfizer following its 2013 spinoff from that firm: "The process of separating from a larger company is fairly unusual... it can be challenging to manage the evolving relationship with the company from which you're separating. In most cases the former parent company will continue to be a supplier, a shareholder, or a customer, or you'll have service agreements with it - and even 
though you've been doing business together for a long time, the relationship and priorities change" (Alaix, 2014: 44).

Thus, even though the value of divesting a spinoff firm is likely to be positive, the challenge faced by the parent firm is that it no longer has full control over the spinoff firm, as it did when that entity was a subsidiary within the parent firm pre-spinoff. This should limit the parent firm's ability to arrange any ongoing post-spinoff interactions with the spinoff firm in such a way as to maximize the positive value it realizes from divesting the spinoff firm. Accordingly, it stands to reason that it would be beneficial for a parent firm to have the power to structure its post-spinoff relationship with its spinoff firm in a way that maximizes the parent firm's gains from the new arrangement.

A unique characteristic of spinoffs gives parent firms this power. In publicly-traded American firms, the primary governing body is the board of directors, whose responsibilities include appointing the top management team and setting its compensation, establishing the company's strategic goals and direction, and monitoring management to ensure that it takes actions that maximize shareholder value. In contrast to the normal process of director nominations, in which the spinoff firm's nominating committee would propose the appointment of a slate of directors and the spinoff firm's shareholders would then vote by proxy on these nominations, the parent firm bears the responsibility of appointing the spinoff firm's initial board of directors. According to the 2013 Spinoff Guide produced by the major corporate law firm, Wachtell, Rosen, Lipton, and Katz, this includes the right of parent firms to nominate their own directors to serve simultaneously on their spinoff firms' boards:

Because a spinoff company is typically a wholly owned subsidiary or is created as a wholly owned subsidiary of the parent, its corporate structure, charter and by-laws can be established by the parent without holding a vote of public shareholders. The parent will need to select the jurisdiction of incorporation of the spinoff company, draft its constitutive documents such as its charter and bylaws, and determine the size and composition of the board of directors, as well 
as board compensation and the structure of board committees. The parent will also need to decide whether members of the parent's board will be moved to (or sit concurrently on) the board of the spinoff company. It is possible for a parent and the spinoff company to have overlapping directors. Any overlap in directors between the parent and the spin-off company generally is limited to at most a minority of each board in order to preserve the tax-free nature of the spin-off. All of the facts and circumstances should be considered in determining the impact of overlapping directors on the tax treatment of the spinoff.

Accordingly, a parent firm's right to appoint its own representatives to its spinoff firm's board gives the parent firm power by affording it a voice in the spinoff firm's decision-making and strategy-setting processes. As will now be discussed, these "dual directors" can use that power in one of two ways: to coordinate the spinoff firm's actions with the parent firm's planned strategies and desired outcomes, or to advance the parent firm's interests at the spinoff firm's expense. The question this raises is when will the latter effect predominate over the former, or, put differently, when will dual directors exercise power on behalf of the parent firm in a way that is not beneficial for the spinoff firm? To address this question, it is necessary to draw on transaction cost economics and resource dependence theory, two paradigms offering insights that speak to the possible roles that dual directors might play.

\section{Dual Directors Facilitating Coordination}

The core strategic issue in transaction cost economics (TCE) is the choice of governance mode: when deciding how to govern a transaction, firms select the governance modemarket, hierarchy, or hybrid - that economizes on the costs of conducting that transaction (Coase, 1937; Williamson, 1975, 1985). Analogously to Reuer's (2001) conceptualization of the internalization of alliances as a shift from market to hierarchy, spinoffs can be thought of as a shift from a hierarchy-based mode of governance, in which a subsidiary is fully integrated within its parent firm, to a market-based mode of governance, in which the spinoff firm 
is formally disintegrated from its parent firm. By undertaking a spinoff, the parent firm acknowledges that the transaction costs of its post-spinoff relationship with its independent spinoff firm are lower than those of its pre-spinoff relationship with its formerly-internalized subsidiary. As a result, the parent firm is willing to spin off that business unit.

Just as alliances require "significant coordination of activities between the partners and yet have to be managed without the benefit of the structure and systems available in traditional hierarchies" (Gulati \& Singh, 1998: 784), the new organizational mode that now exists between the parent and spinoff firms requires some kind of governance mechanism, since, by having undertaken a spinoff, the parent firm has lost the control and fiat over the divested business unit that internalization previously afforded it. Shervani et al. (2007) theorize and find evidence that a firm's "market power," defined as its "ability to influence the actions of others," might enable it "to effectively manage relationships with independent intermediaries without extreme transction costs because processes associated with bargaining, assembling information, and coordinating channel relationships should be facilitated by the possession of market power" (639-640, emphasis added). The noteworthy insight to emerge from this study is that when there is asymmetric power between two firms, the standard TCE prediction of "efficient" governance design appears not to hold, since one firm's power over the other effectively substitutes for the protections of internalization. Thus, analogously to Shervani et al. (2007), by situating representatives of a parent firm on the board of a spinoff firm, dual directors give that parent firm power over its spinoff firm, in a sense substituting for the control that internalization previously afforded the parent firm over its spun-off subsidiary.

How might dual directors exercise power on behalf of a parent firm? In theory, dual directors could actively advocate for the parent firm's interests, regardless of whether or not its strategic aims are consistent with the spinoff firm's interests. However, this would not be expected to occur in most situations. For one thing, the power that dual directors exercise is likely to be more subtle, deriving from the implication that these directors could take action on behalf of the parent firm (and at the expense of the spinoff firm) if it became necessary to 
do so, and from the resulting deference that the remainder of the spinoff firm's board might exhibit towards them. For another, the fact that parent firms are usually stronger than their spinoff firms to begin with should reduce the number of instances in which dual directors would even need to subsume the spinoff firm's interests to the parent firm's.

Rather, the manner in which dual directors would be expected to exercise power on behalf of a parent firm might instead be to manage "the complexity of ongoing coordination of activities to be completed jointly or individually across organizational boundaries and the difficulties associated with decomposing tasks and specifying a precise division of labor... all of which require ongoing communication and decisions" (Gulati \& Singh, 1998: 784). This could manifest itself in a number of ways. Just as Shervani et al. (2007) describe a manufacturer's market power over its channel intermediaries as affording it "significant monitoring and surveillance capabilities, as well as the ability to exercise legitimate authority and offer a varied set of incentives to associated channel members" (646), in a similar way, dual directors might monitor, shape the policies of, glean information from, or serve as a communication channel to and from the spinoff firm-overall, simply ensuring that the parent firm's interests are represented to and taken into consideration by the spinoff firm's board in its deliberations and decisions about that company's strategic goals and actions.

In some situations, moreover, the presence of dual directors might even help the spinoff firm, to the extent that the strategic direction in which dual directors orient the spinoff firm on behalf of the parent firm also advances the spinoff firm's interests. This point is reinforced by Shervani et al. (2007), who note, "Firms with high market power can provide guidance to intermediaries on appropriate behaviors that lead to desired outcomes; intermediaries are likely to be receptive to such guidance from them" (640, emphasis added). More generally, a spinoff firm's board is a core strategic resource (Seward \& Walsh, 1996), in that directors are a key source of information, knowledge, capabilities, and expertise (Westphal \& Frederickson, 2001; Hillman, 2005; Kroll, Walters, \& Wright, 2008; McDonald, Westphal, Graebner, 2008; Lester et al., 2008). All of these attributes should be important for a spinoff firm, which 
must overcome its liability of newness and attain legitimacy in the marketplace (Stinchcombe, 1965; Pfeffer \& Salancik, 1978; Certo, 2003; Deutsch \& Ross, 2003), and these benefits may be amplified among dual directors in particular due to their experience with the spinoff firm from its days as a subsidiary of the parent firm (Semadeni \& Cannella, 2011). Put slightly differently, dual directors could fulfill the advisory role described by Adams and Ferreira (2007) and Adams (2009), by which "the board draws upon the expertise of its members to counsel management on the firm's strategic direction" (Adams \& Ferreira, 2007: 218).

Together, these points underscore the coordinative role that dual directors would be expected to play in most circumstances, suggesting that dual directors have the ability to exercise power over the spinoff firm's actions in support of the parent firm's interests, but not the motivation to exercise that power in a manner that is harmful to the spinoff firm. Accordingly, the presence of dual directors would be expected to be beneficial for the parent and spinoff firms, or at worst, beneficial for the parent firm and neutral for the spinoff firm, implying a positive average effect across the two companies.

Hypothesis 1. The average performance of a parent-spinoff firm pair that shares one or more dual directors will exceed that of a parent-spinoff firm pair that shares no dual directors.

\section{Dual Directors and the Costly Exercise of Power}

The foregoing discussion suggests that while dual directors have the ability to exercise power over a spinoff firm on behalf of its parent company, these board members will generally not do so in a manner that is harmful to the spinoff firm. The question that this raises is when dual directors will have the motivation to exercise power on behalf of the parent firm in a way that is costly to its spinoff firm. While TCE alone is insufficient to address this issue, resource dependence theory (RDT) offers a set of tools with which to explore this boundary condition, elucidating when and how dual directors might have the incentive to further the parent firm's interests at the expense of the spinoff firm's interests. 
In RDT's conceptualization, dependence (and its obverse, power) results from one firm's control of resources that another firm values but cannot obtain elsewhere (Emerson, 1962; Pfeffer \& Salancik, 1978). Each of the firms in a given relationship may be dependent on the other for certain resources, and power imbalances arise when one firm is more dependent on its counterpart than the reverse (Casciaro \& Piskorski, 2005). When the magnitude of the power imbalance between two firms is large, the more-powerful firm may have the incentive to structure its interactions with the less-powerful firm to come at that company's expense. For example, dominant firms in exchange relationships might set transaction terms in a manner that is favorable for themselves but costly to their counterparts (Gulati \& Sytch 2007), and powerful firms in keiretsu affiliations appear to direct the flow of scarce financial resources to further their strategic aims, thereby precluding the weak firms in those business groups from attaining their own goals (Kim, Hoskisson, \& Wan, 2004).

Accordingly, when a spinoff firm's dependence on its parent firm is significant, TCE and RDT together suggest that dual directors will have both the means and the motive to exercise power on behalf of the parent firm in a way that is costly to the spinoff firm. One circumstance in which this is quite likely to occur is when the parent firm continues to buy output from the spinoff firm following the separation of the two companies. These buyer-supplier relationships appear to occur reasonably frequently in practice: for example, both Marathon Oil and ConocoPhillips spun off their downstream operations (Marathon Petroleum and Phillips 66, respectively) and both Ford and General Motors spun off their auto parts suppliers (Visteon and Delphi, respectively), yet these parent companies continued to buy power and auto parts, respectively, from the spinoff firms they had divested. Similarly, while Coca-Cola spun off its bottling assets into Coca-Cola Enterprises (CCE) in 1986, CCE continued bottling Coca-Cola products after the deal's completion, so much so that CocaCola ultimately re-acquired CCE in 2010.

When a spinoff firm makes a large share of its sales to its parent firm, dual directors would be expected to have both the ability and the motivation to improve the parent firm's 
outcomes at the expense of the spinoff firm. For example, a parent company that sourced certain supplies from its spun-off subsidiary pre-spinoff might still need those supplies postspinoff, but now has a choice of whether to use its spinoff firm or other (potentially more efficient) suppliers. Analogously to the point that stronger manufacturers in the automotive industry used "adversarial tactics" to appropriate value from their weaker suppliers, such as "maintain[ing] large number of suppliers to play them off against each other for price concessions, purposefully [keeping] them at arm's length to maintain advantage, strategically allocat[ing] purchasing volumes to keep them in line... and, in one extreme case, even audit[ing] weaker suppliers to ensure that the latter would earn no excessive profits on exchange transactions" (Gulati \& Sytch, 2007: 36), the role of dual directors in these situations might be to advocate for the spinoff firm to offer better terms to its former parent for fear of losing the business to other suppliers. Unfortunately, the fact that the spinoff firm may have few (if any) alternate exchange partners other than its parent company in these circumstances gives the spinoff firm little recourse (Emerson, 1962; Casciaro \& Piskorski, 2005).

Wachtell, Rosen, Lipton, and Katz's 2013 Spinoff Guide makes the important point that in situations where the spinoff and parent firms' interests are at odds with one another, dual directors may need to recuse themselves from the relevant deliberations in order to uphold their fiduciary duties to the shareholders of each of the companies they serve: "If a company determines to have overlapping directors with a spin-off company, it should consider the possibility that conflicts may arise between the parent and the spin-off company that may make it appropriate for a director to recuse himself or herself from deliberations at each company's board." With this being said, however, American corporate boardrooms are typically characterized by collegial cultures and norms of reciprocity (Mace, 1971; Useem, 1984; Lorsch \& MacIver, 1989; Wade, O’Reilly, \& Chandratat, 1990), and dual directors may have a great deal of status on spinoff firms' boards due to their history with and continuing service on the parent firms' boards (Feldman \& Montgomery, 2015). This suggests that even if dual directors were to recuse themselves from deliberations in which the parent and 
spinoff firms' interests were in conflict, the remainder of the directors on the spinoff firm's board might exhibit deference to dual directors' preferences and opinions, perpetuating these directors' power to advance the parent firm's interests at the spinoff firm's expense.

As noted by Casciaro and Piskorski (2005), "the most likely result of a power imbalance is that [the more powerful exchange partner] will appropriate a larger portion of the overall benefits accruing from the exchange" (172). Along similar lines, Gulati and Sytch (2007) point out, “...the degree of a manufacturer's dependence advantage enhance[s] its performance in exchange relationships with suppliers... thereby redistributing value in the relationship in their own favor" (36). These points suggest that as the spinoff firm's sales dependence on its parent firm grows, dual directors have both the ability (due to their presence on the spinoff firm's board and their involvement in its deliberations and decision-making processes, as implied by TCE) and the motivation (due to the parent firm's opportunity to profit from the spinoff firm's sales dependence, as implied by RDT) to exploit the parent firm's increasingly asymmetric power over the spinoff firm, resulting in a redistribution of value from the spinoff firm to the parent firm.

Hypothesis 2. The larger the share of sales a spinoff firm makes to its parent firm, the more the performance of a parent firm that has one or more dual directors on its board will exceed that of a parent firm with no dual directors.

Hypothesis 3. The larger the share of sales a spinoff firm makes to its parent firm, the more the performance of a spinoff firm that has one or more dual directors on its board will fall short of that of a spinoff firm with no dual directors. 


\section{METHODS}

\section{Sample}

The sample employed in this paper consists of 228 spinoffs undertaken by 196 Fortune 500 firms between 1995 and 2010. I initially used SDC Platinum's Mergers and Acquisitions database to compile a list of all spinoffs that were announced and completed between January 1, 1995 and December 31, 2009. 761 total spinoffs were undertaken during this fifteen-year period. I then identified the firms that were in the Fortune 500 at any point between 1995 and 2009, inclusive. This decision rule helped avoid survivor bias by ensuring that even if the company entered the Fortune 500 after 1995 or departed prior to 2010, it remained in the sample. I then matched the sample of Fortune 500 companies to the list of spinoffs to identify the Fortune 500 firms that had undertaken spinoffs during this period of time. There were 260 such spinoffs. Thirty-two of these transactions were eliminated because SDC had mis-classified tracking stock issuances as spinoffs (e.g. Applera's 1999 tracking stock issuance for Celera Genomics) or because the spinoff firm lost its independence through acquisition, bankruptcy or some other transaction immediately following the completion of the spinoff (e.g. Cargill's acquisition of Agribrands International immediately following its 1998 spinoff from Ralston Purina). ${ }^{1}$ Thus, the final sample analyzed in this paper consists of 228 spinoffs.

\section{Data}

The majority of the data employed in this paper was hand-collected from three sources: the annual proxy statements filed by the divesting parent firms, the annual proxy statements filed by the divested spinoff firms, and the registration statements filed by the spinoff firms upon the completion of their spinoffs. These filings are all accessible electronically from the Securities and Exchange Commission's (SEC) EDGAR database.

\footnotetext{
${ }^{1}$ The elimination of these thirty-two deals did not bias the sample, in that the financial characteristics of the divesting firms were not statistically different from those of the firms that remained in the sample.
} 
The proxy statements provided access to information about the directors serving on the boards of the parent and spinoff firms. For each parent firm and each spinoff firm, data were gathered for the year in which the spinoffs took place, as well as the three years thereafter. Thus, in the empirical models that follow, four-year panels of post-spinoff data are analyzed for each parent firm and each spinoff firm.

To supplement these director-level data, I used Compustat and CRSP to gather financial and stock market data for the parent and spinoff firms. Additionally, I used the registration statements to collect pre-spinoff financial information on the spinoff firms (i.e., when these entities were subsidiaries of their parent companies), some of which was used to construct the variables measuring the spinoff firms' sales dependence on their parent firms.

\section{Variables}

Dependent Variable. One of the unique features of corporate spinoffs is that it is possible to measure both the average and individual performance of the parent and spinoff firms involved in these deals. Accordingly, annual stock returns $\left(\mathrm{R}_{t}\right)$ are defined as follows: $\left(\mathrm{P}_{t}+\operatorname{Div}_{t}-\mathrm{P}_{t-1}\right) / \mathrm{P}_{t-1}$, where $\mathrm{P}_{t}$ represents the end-of-year stock price in year $\mathrm{t}$ and $\mathrm{Div}_{t}$ represents dividends in year $\mathrm{t}$.

To test Hypothesis 1, Value-Weighted Returns is defined as the value-weighted, average annual stock market returns of the parent and spinoff firms: $\left[\mathrm{V}_{t}^{P} /\left(\mathrm{V}_{t}^{P}+\mathrm{V}_{t}^{S}\right)\right] \times \mathrm{R}_{t}^{P}+$ $\left[\mathrm{V}_{t}^{S} /\left(\mathrm{V}_{t}^{P}+\mathrm{V}_{t}^{S}\right)\right] \times \mathrm{R}_{t}^{S}$, where $\mathrm{V}_{t}^{P}$ represents the parent firm's end-of-year market capitalization in year $\mathrm{t}, \mathrm{V}_{t}^{S}$ represents the spinoff firm's end-of-year market capitalization in year t, $\mathrm{R}_{t}^{P}$ represents the parent firm's annual stock returns in year t, and $\mathrm{R}_{t}^{S}$ represents the spinoff firm's annual stock returns in year t. It is necessary to construct this variable in this manner because parent firms are typically much larger in size than their spinoff firms. Weighting each firm's independent stock market returns by its relative size accounts for this discrepancy.

To test Hypotheses 2 and 3, the dependent variables are, respectively, Parent Annual Stock Returns $\left(\mathrm{R}_{t}^{P}\right)$ and Spinoff Annual Stock Returns $\left(\mathrm{R}_{t}^{S}\right)$, both as defined above. 
Key Independent Variables. To represent the presence of dual directors on parent and spinoff firm boards, Firm Has Dual Director is an indicator variable that takes the value one if a parent-spinoff firm pair shares at least one common director, and zero if not.

Hypotheses 2 and 3 are about the performance implications of dual directors contingent on the share of sales the spinoff firm makes to the parent firm. I represent the existence of such exchange relationships using Share of Sales, a variable that takes the value of the spinoff firm's total sales to its parent firm scaled by the spinoff firm's total sales, both measured in the year pre-spinoff, in all of the post-spinoff years. Large Share of Sales is similarly defined as an indicator variable taking the value one in all post-spinoff years if Share of Sales exceeds the median value of that variable's distribution in the year pre-spinoff. ${ }^{2}$

Control Variables. $\ln$ (Total Assets), defined as the natural log of total assets, represents firm size. Leverage is calculated as the sum of short- and long-term debt scaled by market capitalization, measuring a firm's indebtedness (Chemmanur \& Yan, 2004). Capex/PPE measures a firm's capital intensity and is defined as its total capital expenditures scaled by its net property, plant, and equipment. Negative Net Income is an indicator variable taking the value one if a firm has negative net income, representing financially-distressed firms. Number of Segments is a count of the number of business segments in which a firm operates. Industry Sales Growth is defined as the average sales growth rate of all single-segment firms operating in each company's main three-digit SIC code. Finally, Total Directors is

\footnotetext{
${ }^{2}$ The ideal way to represent a spinoff firm's sales dependence on its parent firm would be to measure the share of sales the spinoff firm makes to its parent firm in the post-spinoff years, but unfortunately, such data are not publicly available. As such, Share of Sales and Large Share of Sales respectively use the intensity and existence of the pre-spinoff sales dependence of the spun-off subsidiary on its parent firm as proxies for the post-spinoff sales dependence of the spinoff firm on its parent firm. These approximations rest on the assumption that in spinoffs where the spun-off subsidiary made a large share of its sales to the parent firm pre-spinoff, such exchange relationships are likely to persist post-spinoff. To test the validity of this assumption, I also ran all of my empirical models using Casciaro and Piskorski's (2005) measure of industry dependence, which is based on the Bureau of Economic Analysis' input-output data on inter-industry flows and industry concentration. I used these data to develop a time-varying measure of the dependence of companies in the spinoff firms' industries as buyers/sellers of output from/to companies in the parent firms' industries. I call this measure Industry Dependence. I also created a time-varying indicator variable, High Industry Dependence, which takes the value one if Industry Dependence exceeds the median value of its distribution in a given year, and zero otherwise. All of the results described in the next section of the paper are robust to the use of Industry Dependence and High Industry Dependence instead of Share of Sales and Large Share of Sales. These results are available upon request from the author.
} 
defined as a firm's total number of board members, and Total Insiders is its total number of independent directors, reflecting board size and board independence, respectively.

Tables 1 and 2 provide summary statistics and correlation matrices for the above-described variables, measured separately for the parent and spinoff firms.

Table 1 and 2 here

\section{Analyses}

I analyze the relationship between the presence of dual directors and performance in two ways. First, I use deal fixed effects regressions to account for the effects of idiosyncratic, deal-specific characteristics on this relationship. ${ }^{3}$ Second, I use treatment effects models with switching regressions (Hamilton \& Nickerson, 2003; Mayer \& Nickerson, 2005; Li \& Prabhala, 2007) to account for the effects of non-random selection on this relationship.

In treatment effects models, a first-stage regression is fitted to predict each firm's propensity to undertake an action (here, to have a dual director on its board), which is considered the treatment. Firms that undertake the action are considered as the treated group, whereas those that do not undertake it are the control group. The estimated propensities are then used in a second-stage regression to measure the performance consequences of having a dual director on the board, accounting for the fact that the decision to do so was not random. Thus, Firm Has Dual Director is the dependent variable in the first-stage regression. The predicted values of this dependent variable are used as the key independent variable in the second-stage regressions, whose dependent variables are Value-Weighted Returns, Parent Annual Stock Returns, and Spinoff Annual Stock Returns.

Treatment effects models require the use of one or more instrumental variables to properly identify the first-stage regression. An appropriate instrument must be correlated with the endogenous variable (Firm Has Dual Director) but not with the outcome variable of interest

\footnotetext{
${ }^{3} \mathrm{I}$ also use generalized estimating equations (GEE) to fit population-averaged panel data models that account for the effects of autocorrelation in my variables. The results of my deal fixed effects regressions are robust to my use of this estimation technique.
} 
(here, Value-Weighted, Parent, and Spinoff Annual Stock Returns). I use two instrumental variables to identify the treatment effects models I employ in this paper, both of which derive from the issue of the distance between the headquarters of the newly-separated parent and spinoff firms (Kono et al., 1998; Tuschke, Sanders, \& Hernandez, 2014; Hernandez, 2014).

First, Geographic Distance is the distance, "as the crow flies," between the two cities in which the parent and spinoff firm headquarters are located. ${ }^{4}$ Second, Daily Direct Flights is a grouped count of the total number of direct flights (0 flights, 1-25 flights, 26-50 flights, ..., 175-200 flights, and 200-250 flights) between the international airport(s) located in or nearest to the cities in which the parent and spinoff firm headquarters are located. ${ }^{5}$

Both of these variables are likely to satisfy the requirements for appropriate instruments. They are both expected to be positively correlated with the likelihood that a given parentspinoff firm pair has a dual director on its board. A parent firm should be more likely to appoint a dual director to its spinoff firm's board when the two companies are located far apart from one another, in that the dual director should enhance the parent firm's ability to monitor and oversee the activities of its spinoff firm in these instances. The number of daily direct flights should also be positively correlated with a parent firm's propensity to appoint a dual director to its spinoff firm's board, since the accessibility of the two corporate headquarters to one another will be greater when there are more direct flights between those two cities. However, neither of these instruments should be correlated with the stock returns of the parent or the spinoff firms, since there is no reason to believe that the geographic

\footnotetext{
${ }^{4}$ These distances were computed using http://www.geobytes.com/CityDistanceTool.htm.

${ }^{5}$ This variable was calculated in two steps. First, the major international airport(s) that are located within 50 miles of the cities in which the parent and spinoff firms' headquarters are located was identified using http://airport.globefeed.com/US_Nearest_Airport.asp. Second, the number of daily direct flights on a standard, non-holiday, mid-week day (Wednesday) was calculated using http://www.flightstats.com/go/FlightSchedules/schedules.do. If no airports were located within 50 miles of a firm's headquarters, the closest major international airport was used. If a city had multiple international airports located within 50 miles of one another (for example, New York City is served by Kennedy, Newark, and LaGuardia Airports), all of those airports were included. If the parent and spinoff firms' headquarters were located within 50 miles of one another or shared the same international airport, zero daily direct flights was assumed, under the presumption that a drive would be more reasonable. Finally, because historical flight data was unavailable, current flight information was used to calculate this variable: while the overall flight volume between city pairs might vary by year, the general level of direct flight activity between pairs of cities should remain relatively consistent over time.
} 
distance or the accessibility of two cities to one another should systematically influence a firm's performance. Thus, Geographic Distance and Daily Direct Flights are appropriate instruments with which to identify this study's treatment effects models.

The switching regressions framework builds on these treatment effects models to test the relationship between the presence of dual directors and firm performance when the spinoff firm makes a large share of its sales to the parent firm. Within this framework, the firststage propensity regression remains as described above, predicting the propensity that a given parent-spinoff firm pair will share at least one dual director. Second-stage regressions, measuring the relationship between the presence of dual directors (as predicted by the firststage regression) and firm performance, are estimated simultaneously for (1) deals in which the spinoff firm makes a large share of sales to the parent firm, and (2) deals in which this is not the case. This approach accounts for the possibility that the coefficients on Firm Has Dual Director might vary by spinoff "type," making it necessary to construct the indicator variable, Large Share of Sales, to identify these two spinoff types. Wald tests are used to measure the significance of the difference between the coefficients on Firm Has Dual Director (Hamilton \& Nickerson, 2003; Mayer \& Nickerson, 2005; Li \& Prabhala, 2007).

\section{RESULTS}

\section{Deal Fixed Effects Models}

Tables 3,4 , and 5 present the results of deal fixed effects regressions testing this paper's three hypotheses. All models include deal and year fixed effects, where the deal fixed effects are measured as indicator variables for each unique parent-spinoff firm pair in the sample and the year fixed effects are measured as indicator variables for each individual year in the sample (1995-2009). Robust standard errors are clustered by deal to account for intra-group correlation across the four years of observations pertaining to each deal. Regression (1) in all three tables includes only lagged control variables. 
In Table 3, the dependent variable is Value-Weighted Returns. The coefficient on Firm Has Dual Director is positive and significant at $5 \%$ in Regression (2), indicating that the value-weighted stock market returns of parent-spinoff firm pairs that share one or more dual directors are about 31 basis points higher than those of parent-spinoff firm pairs that do not share dual directors. A Hausman test of the choice between using fixed and random effects in estimating this regression is rejected at the $1 \%$ level of significance $\left(X^{2}(30)=61.16\right)$, indicating that fixed effects are a more appropriate estimation technique than random effects. This result provides evidence in support of Hypothesis 1, revealing that dual directors are positively associated with the average stock market performance of parent-spinoff firm pairs.

In Table 4, the dependent variable is Parent Annual Stock Returns. The coefficient on Firm Has Dual Director in Regression (2) is positive and significant at 5\%, indicating that the stock market returns of parent firms that have one or more dual directors exceed those of parent firms that have no dual directors by about 47 basis points. A Hausman test of the choice between using fixed and random effects in estimating Regression (2) is rejected at the $5 \%$ level of significance $\left(X^{2}(24)=39.94\right)$, again suggesting that fixed effects are the appropriate estimation technique to use in this instance.

Regressions (3) and (4) incorporate Firm Has Dual Director $\times$ Share of Sales and Firm Has Dual Director $\times$ Large Share of Sales, respectively. While the coefficients on Firm Has Dual Director lose their significance in these two regressions, the coefficients on both of the interaction terms are positive and significant. The coefficient on Firm Has Dual Director $\times$ Share of Sales in Regression (3) reveals that the positive relationship between the presence of one or more dual directors and parent firm performance increases in the share of sales the spinoff firm makes to its parent firm, and the coefficient on Firm Has Dual Director $\times$ Large Share of Sales in Regression (4) indicates that this positive relationship is concentrated among the parent firms that account for a large share of their spinoff firms' sales. Figure 1 represents the latter relationship graphically, showing that the relationship between the presence of 
dual directors and parent firm performance is more positive in deals where the spinoff firm makes a large share of its sales to the parent firm than when this is not the case. Together, these findings therefore provide support for Hypothesis 2.

In Table 5, the dependent variable is Spinoff Annual Stock Returns. The coefficient on Firm Has Dual Director in Regression (2) is negative and significant at 5\%, indicating that that the stock market returns of spinoff firms that have one or more dual directors fall short of those of spinoff firms with no dual directors by about 42 basis points. As in the parent firm results, a Hausman test of the choice between using fixed and random effects in estimating Regression (2) is rejected at the $1 \%$ level of significance $\left(X^{2}(24)=82.14\right)$, suggesting that fixed effects are again the appropriate estimation technique.

Analogously to the previous discussion, Regressions (3) and (4) respectively incorporate Firm Has Dual Director $\times$ Share of Sales and Firm Has Dual Director $\times$ Large Share of Sales. While the coefficients on Firm Has Dual Director again lose their significance in these regressions, the significant coefficient on Firm Has Dual Director $\times$ Share of Sales in Regression (3) reveals that the negative relationship between the presence of one or more dual directors and spinoff firm performance increases in the share of sales a spinoff firm makes to its parent firm. Similarly, the negative and significant coefficient on Firm Has Dual Director $\times$ Large Share of Sales in Regression (4) indicates that this relationship is concentrated among the spinoff firms that make a large share of sales to their parent firms. ${ }^{6}$ Figure 2 represents the latter relationship graphically, showing that the relationship between the presence of one or more dual directors and spinoff firm performance is more negative when the spinoff firm makes a large share of its sales to the parent firm than when this is not the case. In sum, these results provide support for Hypothesis 3.

Figures 1 and 2 here

\footnotetext{
${ }^{6}$ Given the divergent results documented in Tables 4 and 5, it is unsurprising that the coefficients on Firm Has Dual Director $\times$ Share of Sales and Firm Has Dual Director $\times$ Large Share of Sales in Regressions (3) and (4) of Table 3 are not statistically significant. In deals where the spinoff firm makes a large share of its sales to the parent firm, the parent firm's gains from the presence of dual directors come at the expense of the spinoff firm, implying a null average effect across the two companies together.
} 


\section{Treatment Effects Models with Switching Regressions}

While the above-described deal fixed effects models provide initial evidence in support of this paper's hypotheses, they do not account for the effects of non-random selection in the parent-spinoff firm pairs that do and do not share dual directors. To account for this issue, Tables 6 and 7 present the results of treatment effects models with switching regressions.

The baseline treatment effects models appear in Table 6. Regression (1) presents the results of the first-stage regression predicting the likelihood that a parent-spinoff firm pair will share a dual director; its dependent variable is Firm Has Dual Director. The coefficients on the instrumental variables, Geographic Distance and Daily Direct Flights, are positive and significant at $5 \%$. These results suggest that parent-spinoff firm pairs are more likely to share dual directors when the parent and spinoff firms are located farther away from one another, and when there are more direct flights between the cities in which the parent and spinoff firms' headquarters are located. ${ }^{7}$ Additionally, Large Share of Sales is positive and significant, suggesting that dual directors are more likely to be appointed in deals where the spinoff firm makes a large share of sales to its parent firm - that is, in deals where the presence of such directors is likely to be most useful to the parent firm.

Regression (2) in Table 6 presents the results of the treatment effects model's secondstage regression testing the relationship between the presence of dual directors and the valueweighted performance of parent-spinoff firm pairs. The dependent variable in this regression is Value-Weighted Returns, and the coefficient on Firm Has Dual Director is positive and significant, indicating that the value-weighted stock market returns of parent-spinoff firm

\footnotetext{
${ }^{7}$ As evidence of the validity of these instruments, a test that Geographic Distance and Daily Direct Flights are not jointly significantly different from zero is rejected at the $5 \%$ level $\left(X^{2}(2)=6.47\right)$, suggesting that these two instruments are individually and collectively associated with the likelihood that a parent-spinoff firm pair will share one or more dual directors. Furthermore, it is noteworthy that neither of these two variables is significant when they are included in the second-stage regressions. Finally, a Sargan test (whose null hypothesis is that the identifying restrictions are uncorrelated with the residuals in the second-stage regression), is not rejected in the value-weighted $\left(X^{2}(3)=1.17\right)$, parent firm $\left(X^{2}(3)=2.37\right)$, or spinoff firm $\left(X^{2}(3)=2.19\right)$ regressions, indicating that the identifying restrictions in these models are appropriate.
} 
pairs that share one or more dual directors are about 59 basis points higher than those of parent-spinoff firm pairs that do not share dual directors, controlling for the effects of non-random selection. ${ }^{8}$ This result is consistent with that of the deal fixed effects models, providing further evidence in support of Hypothesis 1's prediction that dual directors are positively associated with the average stock market performance of parent-spinoff firm pairs.

Regressions (3) and (4) of Table 6 present the results of the second-stage regressions testing the relationships between Firm Has Dual Director (as predicted by the first-stage regression), and Parent Annual Stock Returns in Regression (3) and Spinoff Annual Stock Returns in Regression (4). The coefficient on Firm Has Dual Director is positive and significant in Regression (3), but negative and significant in Regression (4). These findings indicate that, controlling for the effects of non-random selection, the presence of dual directors is positively associated with parent firm performance, and negatively associated with spinoff firm performance.

Despite the consistency of these findings with earlier results, Hypotheses 2 and 3 make predictions regarding the relationship between the presence of dual directors and firm performance in spinoffs where the spinoff firm makes a large share of its sales to the parent firm. Switching regressions facilitate tests of these hypotheses. In the switching regressions framework, the second-stage regressions in the treatment effects models are estimated simultaneously for each "type" of spinoff: deals in which the spinoff firm makes a large share of its sales to its parent firm, and deals in which this is not the case. Wald tests are used to test the significance of the difference between the two coefficients on Firm Has Dual Director.

Table 7 presents the coefficients on Firm Has Dual Director, as estimated from secondstage switching regressions measuring the relationship between this variable and firm performance in deals where the spinoff firm makes a large share of its sales to its parent firm,

\footnotetext{
${ }^{8}$ Indeed, the significance of the Inverse Mills Ratio suggests that bias due to non-random selection is a potential problem, and the negative sign of the Inverse Mills Ratio indicates negative selection (Mayer \& Nickerson, 2005). Negative selection means that the performance of parent-spinoff firm pairs that have no dual directors on their boards would have been better if they had dual directors on their boards. In other words, the deal fixed effects models that appeared in Table 3 may understate the magnitude of the positive relationship that exists between the presence of dual directors and value-weighted returns.
} 
and in deals where this is not the case. In Panel A, where the dependent variable is Parent Annual Stock Returns and the regression measures deals in which the spinoff firm makes a large share of sales to its parent firm (Large Share of Sales equals one), the coefficient on Firm Has Dual Director is positive and significant at 1\%. By comparison, in Panel B, where the dependent variable is Parent Annual Stock Returns and the regression measures deals in which the spinoff firm does not make a large share of sales to its parent firm (Large Share of Sales equals zero), the coefficient on Firm Has Dual Director is not significant. As shown in Panel C, a Wald test of the equality of these two coefficients is rejected at $5 \%$.

Analogously, in Panel D, where the dependent variable is Spinoff Annual Stock Returns and the regression measures deals in which the spinoff firm makes a large share of sales to its parent firm (Large Share of Sales equals one), the coefficient on Firm Has Dual Director is negative and significant at 1\%. By contrast, in Panel E, where the dependent variable is Spinoff Annual Stock Returns and the regression measures deals in which the spinoff firm does not make a large share of sales to its parent firm (Large Share of Sales equals zero), the coefficient on Firm Has Dual Director is again not significant. As shown in Panel F, a Wald test of the equality of these two coefficients is also rejected at $5 \%$. In sum, these results provide further evidence supporting Hypotheses 2 and 3's predictions that the presence of dual directors will be beneficial for parent firms but costly to spinoff firms when the spinoff firm makes a large share of sales to the parent firm.

\section{DISCUSSION}

\section{Summary of Results}

This study has considered two interrelated research questions: how do dual directors enable firms that undertake spinoffs to manage their post-spinoff relationships with the firms they divest, and what implications does the presence of these directors have for parent and spinoff firm performance? Dual directors are defined as directors who simultaneously serve on 
the boards of parent and spinoff firms that are separated in corporate spinoffs. The presence of one or more dual directors on these firms' boards is positively associated with the average, value-weighted stock market returns of parent-spinoff firm pairs. Additionally, as the share of sales a spinoff firm makes to its parent firm rises, the presence of one or more dual directors becomes increasingly positively associated with parent firm performance, but increasingly negatively associated with spinoff firm performance. These results are derived using deal fixed effects models, which account for the effects of unobserved, deal-specific heterogeneity, as well as treatment effects models with switching regressions, which account for the effects of non-random selection in the parent-spinoff firm pairs that share dual directors.

\section{Theoretical Contributions}

This article makes several important contributions to research about corporate spinoffs, diversified firms, and boards of directors, yielding significant theoretical implications for transaction cost economics and resource dependence theory as well.

The core conceptual insight to emerge from this study is that dual directors give parent firms power over their spinoff firms. Critically, the degree to which a spinoff firm is dependent on its parent firm determines whether dual directors will exercise this power in a manner that is not beneficial for the spinoff firm, which, in turn, drives the implications of the presence of dual directors for both parent and spinoff firm performance.

Parent firms appoint dual directors to arrange their relationships with their spinoff firms in such a way as to maximize their positive expected returns from those deals. While the presence of dual directors gives a parent firm power over its spinoff firm, the circumstances in which dual directors would have the motivation to exercise that power at the spinoff firm's expense are limited because parent firms are usually more powerful than their spinoff firms to begin with. As the spinoff firm's dependence on its parent firm grows, however, dual directors have both the incentive and the ability to exercise power at the spinoff firm's expense, since there are economic benefits for the parent firm to realize from their doing so. 
While these insights are important in and of themselves, their juxtaposition is even more noteworthy: the presence of dual directors is positively associated with the average returns of parent-spinoff firm pairs despite the divergent distributional implications of dual directors for parent and spinoff firm performance when the spinoff firm's sales dependence on its parent firm is high. The implication of this pair of findings is that although dual directors may be value-creating in general, this must be driven by the case in which there is relatively little dependence between the firms. When there is relatively more dependence between the firms, dual directors appear to benefit the parent firm at the expense of the spinoff firm, implying a redistribution rather than a creation of value. Thus, even though dual directors may serve as a value-creating governance mechanism overall, there is still the ethical issue that dual directors appear to exercise their power to play a redistributive role in certain situations, although not in a way that destroys overall value. This finding could help explain why dual directors are a reasonably prevalent phenomenon in practice (close to $60 \%$ of parent-spinoff firm pairs in the sample analyzed in this paper share them in the effective year of their spinoffs), and indeed, why U.S. legal regulations even permit parent firms to appoint them in the first place, as the positive average effect of dual directors appears to "mask" the negative effects of their presence in spinoffs where certain exchange relationships persist.

These insights about spinoffs and dual directors also make some important theoretical contributions to transaction cost economics (TCE) and resource dependence theory (RDT).

First, the key outcome variable in many studies grounded in TCE is the choice of governance mode, that is, the decision to conduct a transaction within a firm (in the hierarchy) or at arms-length (in the market). Analogously to Reuer (2001), who conceptualized the internalization of alliances as a shift from market to hierarchy, this study has treated corporate spinoffs as a shift from hierarchy to market, an approach that has yet to be employed by scholars in this domain. One noteworthy nuance to this treatment of spinoffs as a type of outsourcing or externalization is that in contrast to TCE's traditional representation of outsourcing, which involves taking a transaction done internally and finding a new external 
supplier (Mayer \& Nickerson, 2005; Mayer \& Salomon, 2006), a spinoff represents a situation in which the supplier remains constant but its relationship to the firm changes.

Further to this point, TCE recommends the use of "safeguards" — defined as "mechanisms designed to minimize the risk of subsequent opportunistic exploitation" (Heide, 1994: 73)— in market-based transactions where a firm faces the threat of hold-up because it has made relationship-specific investments with another company. Safeguards can take a number of different forms, including formal mechanisms like detailed contractual clauses (Mayer \& Argyres, 2004; Argyres, Bercovitz, \& Mayer, 2007) and relational mechanisms like trust and repeated exchange (Gulati, 1995; Poppo \& Zenger, 2002; Zollo, Reuer, \& Singh, 2002). While safeguards protect a firm from an opportunistic exercise of power by its counterparty, TCE itself has not addressed how a firm might exercise power over its counterparty. Indeed, TCE has, for the most part, avoided these kinds of inter-firm power differentials.

This study has taken an initial step towards filling this gap by considering how a firm might be able to exercise power over its counterparties in market-based relationships. Rather than functioning as safeguards in the traditional sense of the term (i.e., preventing the spinoff firm from holding up its parent firm), dual directors instead serve as mechanisms that give the parent firm power over the spinoff firm. In a sense, dual directors therefore appear to recreate the hierarchical relationship that existed between the parent and spinoff firms pre-spinoff by substituting for the fiat and control that internalization previously afforded the parent firm over its spun-off subsidiary (Shervani et al., 2007). In sum, these points suggest that TCE's concept of governance mechanisms that are implemented to manage market-based transactions might usefully be expanded to include mechanisms that enable firms to exercise power over their counterparties, in addition to mechanisms that protect firms against opportunistic exercises of power (i.e., safeguards) where relationship-specific investments have been made.

Still further, the introduction of RDT offers an interesting extension to these insights. A core idea from RDT is that when the magnitude of the power imbalance in a given dyad 
becomes significant, the more-powerful firm may be able to claim a greater share of the value deriving from that exchange at the expense of its less-powerful counterpart (Kim et al., 2004; Casciaro \& Piskorski, 2005; Gulati \& Sytch, 2007). In the case of spinoffs, although dual directors give parent firms power over their spinoff firms, the presence of dual directors only becomes costly for a spinoff firm when its dependence on its parent firm as a buyer for its output pushes that power imbalance to the point where redistribution occurs. Together, these ideas suggest that even though TCE might usefully consider the possibility of a firm implementing mechanisms (like dual directors) to exercise power over a counterparty in a market-based relationship, RDT sheds light on an important boundary condition of this idea by elucidating when and how the use of such mechanisms could create the potential for the exploitation of asymmetric power - in situations where the power imbalance between the firms becomes too significant. This insight also provides an interesting counterpoint to RDT's extensive analyses of how weaker firms in power-imbalanced relationships might limit their stronger counterparts' power (Pfeffer \& Salancik, 1978; Hillman, Withers, \& Collins, 2009; Wry, Cobb, \& Aldrich, 2013), such as minimization via symbolic approaches (Santos \& Eisenhardt, 2009), absorption via acquisition or diversification (Casciaro \& Piskorski, 2005), cooperation or cooptation via the establishment of bridging ties (Beckman, Haunschild, \& Phillips, 2004), reconfiguration via political action (Mizruchi, 1989), or "borrowing" the power of third parties (Hallen, Katila, \& Rosenberger, 2014).

Finally, this combination of ideas from TCE and RDT raises a novel insight about how firms exert power over other companies when they alter their corporate scope. Scopeexpanding deals (like mergers, acquisitions, alliances, and joint ventures) are mirror images of scope-reducing deals (like asset sales and spinoffs). However, existing research has devoted a great deal more attention to analyzing how to manage inter-firm relationships in scopeexpanding deals - such as best practices for post-merger integration (Datta, 1991; Larsson \& Finkelstein, 1999; Birkinshaw, Bresman, \& Hakason, 2000) and strategies for effectively structuring and governing alliances and joint ventures (Gulati, 1995; Oxley, 1997; Zollo et 
al., 2002; Kale, Dyer, \& Singh, 2002; Oxley \& Sampson, 2004; Sampson, 2004; Reuer, Ariño, \& Mellewigt, 2006; Reuer \& Ariño, 2007) — than it has to such strategies in scope-reducing deals. This discrepancy may be driven by the insight, as elucidated by this study, that strategies for managing inter-firm relationships in scope-reducing deals are not mirror images of strategies for managing inter-firm relationships in scope-expanding deals.

Specifically, the commonality between scope-expanding and scope-reducing deals is the fact that managers exhibit a desire to retain control, by bringing more assets inside firm boundaries in scope-expanding deals and by exerting influence over divested assets in scopereducing deals. As a result, both types of deals offer managers the potential to inappropriately exercise power. The key difference between scope-expanding and scope-reducing deals is the manner in which these inappropriate exercises of power manifest themselves. In scopeexpanding deals, TCE implies that integration allows managers to meddle in non-value added ways by making "selective intervention" impossible (Williamson, 1975, 1985). By contrast, in scope-reducing deals, RDT suggests that power imbalances enable managers to influence their counterparts in non-value added ways by facilitating redistributions of value.

\section{Limitations and Directions for Future Research}

Despite these important contributions, this article has some limitations, which open up several interesting directions for future research.

First, while this study has analyzed the phenomenon of dual directors by considering the static relationship between their presence and various measures of performance, more work remains to be done to understand the dynamic implications of dual directors. More specifically, while parent firms have the initial responsibility of appointing their spinoff firms' boards of directors, the spinoff firms themselves gain control of this process once they attain their independence, enabling them to remove dual directors from their boards. Alternately, dual directors might depart from the parent firms' boards and only keep their seats on the spinoff firms' boards, or these directors might retire from both firms' boards simultaneously. 
Future research could usefully consider the factors that motivate these different types of dual director departures, as well as their potentially-divergent implications for the involved firms.

Second, this study has treated dual directors as a governance mechanism that parent firms can use to manage their relationships with their spinoff firms. It is important to remember, however, that dual directors have their own professional and financial incentives, characteristics, and motivations. For example, a noteworthy fact that emerges from the data analyzed in this study is that dual directors are nearly always considered to be independent directors on the spinoff firms' boards, even though they are more likely than their fellow directors on these boards to be employees of their parent companies. This has two interesting implications. One is that it suggests that the characteristics of dual directors might have significant consequences for the quality of corporate (rather than transactional) governance in spinoff firms. The second is that it indicates that the concept of director independence, important as it is in academic research and policy discussions about good governance (e.g., Hillman \& Dalziel, 2003; Johnson, Hoskisson, \& Hitt, 1993), may be vulnerable to abuse in spinoffs, given dual directors' clear lack of functional independence from these companies. Such corporate governance issues seem likely to provide fruitful avenues for exploration.

Third, dual directors are a particularly stark manifestation of how a firm might appoint its own board members to other companies as a means of preserving its integration with, and hence, its power over its counterparties. This could raise questions about the generalizability of this paper's findings to other empirical contexts. One interesting direction for future research might therefore be to consider other market-governed transactions in which firms might appoint their own directors to other firms' boards, such as other scope-reducing deals, buyer-supplier exchanges, or even relationships within various kinds of commercial ecosystems. Another direction for further research could also be to consider the roles of top management teams or large shareholders in managing these kinds of relationships. 


\section{Conclusion}

This paper has introduced and begun developing a novel area of inquiry, the governance of corporate spinoffs. Drawing on insights from transaction cost economics and resource dependence theory, this study has conceptualized dual directors as a mechanism that gives parent firms the power to manage their post-spinoff relationships with their spinoff firms. While dual directors are value-creating overall, their presence has divergent distributional implications as the spinoff firm's sales dependence on its parent firm grows. These results illustrate how parent firms might strategically appoint dual directors to exercise power over their newly-independent spinoff firms, at times in ways that are harmful to those companies. 


\section{REFERENCES}

Adams, R. B. 2009. Asking directors about their dual roles. Working Paper.

Adams, R. B. \& Ferreira, D. 2007. A theory of friendly boards. Journal of Finance, 62(1): $217-250$.

Alaix, J. R. 2014. How I did it... The CEO of Zoetis on how he prepared for the top job. Harvard Business Review, 92(6): 41-44.

Argyres, N. S., Bercovitz, J., \& Mayer, K. J. 2007. Complementarity and evolution of contractual provisions: an empirical study of IT services contracts. Organization Science, 18(1): 3-19.

Beckman, C. M., Haunschild, P. M., \& Phillips, D. J. 2004. Friends or strangers? Firmspecific uncertainty, market uncertainty, and network partner selection. Organization Science, 15(3): 259-275.

Bergh, D. D. 1995. Size and relatedness of units sold: an agency theory and resourcebased perspective. Strategic Management Journal, 16(3): 221-239.

Bergh, D. D., Johnson, R. A., \& DeWitt, R.-L. 2008. Restructuring through spin-off or selloff: transforming information asymmetries into financial gain. Strategic Management Journal, 29: 133-148.

Berry, H. 2010. Why do firms divest? Organization Science, 21(2): 380-396.

Birkinshaw, J., Bresman, H., \& Hakanson, L. 2000. Managing the postacquisition integration process: how the human integration and task integration processes interact to foster value creation. Journal of Management Studies, 37(3): 395-425.

Brauer, M. 2006. What have we acquired and what should we acquire in divestiture research? A review and research agenda. Journal of Management, 32(6): 751-785.

Capron, L., Mitchell, W., \& Swaminathan, A. 2001. Asset divestiture following horizontal acquisitions: a dynamic view. Strategic Management Journal, 22(9): 817-844.

Casciaro, T. \& Piskorski, M. 2005. Power imbalance, mutual dependence, and constraint absorption: a closer look at resource dependence theory. Administrative Science Quarterly, 50(2): 167-199.

Certo, S. T. 2003. Influencing initial public offering investors with prestige: signaling with board structures. The Academy of Management Review, 28(3): 432-446.

Chang, S. J. 1996. An evolutionary perspective on diversification and corporate restructuring: entry, exit, and economic performance during 1981-89. Strategic Management Journal, 17(8): 587-611. 
Chemmanur, T. J. \& Yan, A. 2004. A theory of corporate spin-offs. Journal of Financial Economics, 72(2): 259-290.

Coase, R. H. 1937. The nature of the firm. Economica, 4(16): 386-405.

Comment, R. \& Jarrell, G. A. 1995. Corporate focus and stock returns. Journal of Financial Economics, 37(1): 67-87.

Corley, K. G. \& Gioia, D. A. 2004. Identity ambiguity and change in the wake of a corporate spin-off. Administrative Science Quarterly, 49(2): 173-208.

Daley, L., Mehrotra, V., \& Sivakumar, R. 1997. Corporate focus and value creation: evidence from spinoffs. Journal of Financial Economics, 45: 257-281.

Datta, D. K. 1991. Organizational fit and acquisition performance: effects of post-acquisition integration. Strategic Management Journal, 12(4): 281-297.

Desai, H. \& Jain, P. C. 1999. Firm performance and focus: long-run stock market performance following spinoffs. Journal of Financial Economics, 54: 75-101.

Deutsch, Y. \& Ross, T. W. 2003. You are known by the directors you keep: reputable directors as a signaling mechanism for young firms. Management Science, 49(8): 10031017.

Emerson, R. M. 1962. Power-dependence relations. American Sociological Review, 27(1): $31-41$.

Feldman, E. R. 2014. Legacy divestitures: motives and implications. Organization Science, 25(3): 815-832.

Feldman, E. R., Gilson, S. C., \& Villalonga, B. 2014. Do analysts add value when they most can? Evidence from corporate spin-offs. Strategic Management Journal, 35(10): 1446-1463.

Feldman, E. R. \& Montgomery, C. A. 2015. Are incentives without expertise sufficient? Evidence from Fortune 500 firms. Strategic Management Journal, 36(1): 113-122.

Gilson, S. 2000. Analysts and information gaps: lessons from the UAL buyout. Financial Analysts Journal, Nov-Dec: 82-110.

Gilson, S. C., Healy, P. M., Noe, C. F., \& Palepu, K. G. 2001. Analyst specialization and conglomerate stock breakups. Journal of Accounting Research, 39(3): 565-582.

Gulati, R. 1995. Social structure and alliance formation patterns: a longitudinal analysis. Administrative Science Quarterly, 38(1): 619-652.

Gulati, R. \& Singh, H. 1998. The architecture of cooperation: managing coordination costs and appropriation concerns in strategic alliances. Administrative Science Quarterly, 43(4): 781-814. 
Gulati, R. \& Sytch, M. 2007. Dependence asymmetry and joint dependence in interorganizational relationships: effects of embeddedness on a manufacturer's performance in procurement relationships. Administrative Science Quarterly, 52(1): 32-69.

Hallen, B. L., Katila, R., \& Rosenberger, J. D. 2014. Unpacking social defenses: a resourcedependence lens on technology ventures, venture capital, and corporate relationships. Academy of Management Journal, forthcoming.

Hamilton, B. H. \& Nickerson, J. A. 2003. Correcting for endogeneity in strategic management research. Strategic Organization, 1(1): 51-78.

Hayward, M. L. \& Shimizu, K. 2006. Decommitment to losing strategic action: evidence from the divestiture of poorly performing acquisitions. Strategic Management Journal, 27(6): 541-557.

Heide, J. B. 1994. Interorganizational governance in marketing channels. Journal of Marketing, 58(1): 71-85.

Helfat, C. E. \& Eisenhardt, K. M. 2004. Inter-temporal economies of scope, organizational modularity, and the dynamics of diversification. Strategic Management Journal, 25(13): 1217-1232.

Hernandez, E. 2014. Finding a home away from home: effects of immigrants on firms' foreign location choice and performance. Administrative Science Quarterly, 59(1): 73-108.

Hillman, A. J. 2005. Politicians on the board of directors: do connections affect the bottom line? Journal of Management, 31: 464-481.

Hillman, A. J. \& Dalziel, T. 2003. Boards of directors and firm performance: integrating agency and resource dependence perspectives. Academy of Management Review, 28(3): 383-396.

Hillman, A. J., Withers, M. C., \& Collins, B. J. 2009. Resource dependence theory: a review. Journal of Management, 35(6): 1404-1427.

Johnson, R. A., Hoskisson, R. E., \& Hitt, M. A. 1993. Board of director involvement in restructuring: the effects of board versus managerial controls and characteristics. Strategic Management Journal, 14: 33-50.

Kaul, A. 2012. Technology and corporate scope: firm and rival innovation as antecedents of corporate transactions. Strategic Management Journal, 33(4): 347-367.

Kale, P., Dyer, J. H., \& Singh, H. 2002. Alliance capability, stock market response, and longterm alliance success: the role of the alliance function. Strategic Management Journal, 23(8): 747-767.

Kim, H., Hoskisson, R. E., \& Wan, W. P. 2004. Power dependence, diversification strategy, and performance in Keiretsu member firms. Strategic Management Journal, 25: 613636. 
Kono, C., Palmer, D., Friedland, R., \& Zafonte, M. 1998. Lost in space: the geography of corporate interlocking directorates. American Journal of Sociology, 103(4): 863-911.

Kroll, M., Walters, B. A., \& Wright, P. 2008. Board vigilance, director experience, and corporate outcomes. Strategic Management Journal, 29: 363-382.

Larsson, R. \& Finkelstein, S. 1999. Integrating strategic, organizational, and human resource perspectives on mergers and acquisitions: a case survey of synergy realization. Organization Science, 10(1): 1-26.

Lee, D. \& Madhavan, R. 2010. Divestiture and firm performance: a meta-analysis. Journal of Management, 36(6): 1345-1371.

Lester, R. H., Hillman, A., Zardkoohi, A., Cannella, A. A. 2008. Former government officials as outside directors: the role of human and social capital. Academy of Management Journal, 51(5): 999-1013.

Li, K. \& Prabhala, N. R. 2007. Self-Selection Models in Corporate Finance. In Eckbo, B.E. Handbook of corporate finance: empirical corporate finance. Elsevier, North Holland: 37-86.

Lorsch, J. W. \& MacIver, E. 1989. Pawns or potentates: the reality of America's corporate boards. Boston, MA: Harvard Business Press.

McDonald, M. L., Westphal, J. D., \& Graebner, M. E. 2008. What do they know? The effects of outside director acquisition experience on firm acquisition performance. Strategic Management Journal, 29: 1155-1177.

Mace, M. L. 1971. Directors: myth and reality. Boston, MA: Harvard Business Press.

Markides, C. 1992. The consequences of corporate refocusing: ex-ante evidence. Academy of Management Journal, 35(2): 398-412.

Markides, C. 1995. Diversification, restructuring, and economic performance. Strategic Management Journal, 16(2): 101-118.

Mayer, K. J. \& Argyres, N. S. 2004. Learning to contract: evidence from the personal computer industry. Organization Science, 15(4): 394-410.

Mayer, K. J. \& Nickerson, J. A. 2005. Antecedents and performance implications of contracting for knowledge workers: evidence from information technology services. Organization Science, 16(3): 225-242.

Mayer, K. J. \& Salomon, R. M. 2006. Capabilities, contractual hazards, and governance: integrating resource-based and transaction cost perspectives. Academy of Management Journal, 49(5): 942-959. 
Miles, J. A. \& Woolridge, J. R. 1999. Spin-offs and equity carve-outs: achieving faster growth and better performance. Morristown, NJ: Financial Executives Research Foundation.

Mizruchi, M. S. 1989. Similarity of political behavior among large American corporations. American Journal of Sociology, 95(2): 401-424.

Moschieri, C. 2011. The implementation and structuring of divestitures: the unit's perspective. Strategic Management Journal, 32: 368-401.

Oxley, J. E. 1997. Appropriability hazards and governance in strategic alliances: a transaction cost approach. Journal of Law, Economics, \& Organization, 13(2): 387-409.

Oxley, J. E. \& Sampson, R. C. 2004. The scope and governance of international R\&D alliances. Strategic Management Journal, 25(8-9): 723-749.

Pfeffer, J. \& Salancik, G. 1978. The external control of organizations: a resource dependence perspective. New York, NY: Harper \& Row.

Poppo, L. \& Zenger, T. 2002. Do formal contracts and relational governance function as substitutes or complements? Strategic Management Journal, 23(8): 707-725.

Reuer, J. J. 2001. From hybrids to hierarchies: shareholder wealth effects of joint venture partner buyouts. Strategic Management Journal, 22(1): 27-44.

Reuer, J. J. \& Ariño, A. 2007. Strategic alliance contracts: dimensions and determinants of contractual complexity. Strategic Management Journal, 28(3): 313-330.

Reuer, J. J., Ariño, A., \& Mellewigt, T. 2006. Entrepreneurial alliances as contractual forms. Journal of Business Venturing, 21(3): 306-325.

Sampson, R. C. 2004. The cost of misaligned governance in R\&D alliances. Journal of Law, Economics, \& Organization, 20(2): 484-526.

Santos, F. M. \& Eisenhardt, K. M. 2009. Constructing markets and shaping boundaries: entrepreneurial power in nascent fields. Academy of Management Journal, 52(4): 643671.

Semadeni, M. \& Cannella, A. A. 2011. Examining the performance effects of post spin-off links to parent firms: should the apron strings be cut? Strategic Management Journal, 32: 1083-1098.

Seward, J. K. \& Walsh, J. P. 1996. The governance and control of voluntary corporate spin-offs. Strategic Management Journal, 17(1): 25-39.

Shervani, T. A., Frazier, G., \& Challagalla, G. 2007. The moderating influence of firm market power on the transaction cost economics model: an empirical test in a forward channel integration context. Strategic Management Journal, 28(6): 635-652. 
Shimizu, K. 2007. Prospect theory, behavioral theory, and the threat-rigidity thesis: combinative effects on organizational decisions to divest formerly acquired units. Academy of Management Journal, 50(6): 1495-1514.

Sorkin, A. R. 2014. The Mergers and Acquisitions Cycle: Buy. Divide. Conquer. The New York Times, December 11, 2014: F-1.

Stinchcombe, A. L. 1965. Social structure and organizations. In J. G. March (Ed.), Handbook of organizations: 142-193. Chicago, IL: Rand McNally \& Company.

Surowiecki, J., 2014. Le divorce. The New Yorker, 90(34): 35.

Tripsas, M. 2009. Technology, identity, and inertia through the lens of "The Digital Photography Company". Organization Science, 20(2): 441-460.

Tuschke, A., Sanders, W. M., \& Hernandez, E. 2014. Whose experience matters in the boardroom? The effects of experiential and vicarious learning on emerging market entry. Strategic Management Journal, 35(3): 398-418.

Useem, M. 1984. The inner circle. Oxford, UK: Oxford University Press.

Wade, J., O'Reilly III, C. A., \& Chandratat, I. 1990. Golden parachutes: CEOs and the exercise of social influence. Administrative Science Quarterly, 35(4): 587-603.

Westphal, J. D. \& Frederickson, J. W. 2001. Who directs strategic change? Director experience, the selection of new CEOs, and change in corporate strategy. Strategic Management Journal, 22: 1113-1137.

Williamson, O. E. 1975. Markets and hierarchies. New York: Free Press.

Williamson, O. E. 1985. The economic institutions of capitalism. New York: Free Press.

Wry, T., Cobb, J. A., \& Aldrich, H. E. 2013. More than a metaphor: assessing the historical legacy of resource dependence and its contemporary promise as a theory of environmental complexity. Academy of Management Annals, 7(1): 439-486.

Zollo, M., Reuer, J. J., \& Singh, H. 2002. Interorganizational routines and performance in strategic alliances. Organization Science, 13(6): 701-713.

Zuckerman, E. W. 2000. Focusing the corporate product: securities analysts and dediversification. Administrative Science Quarterly, 45(3): 591-619. 


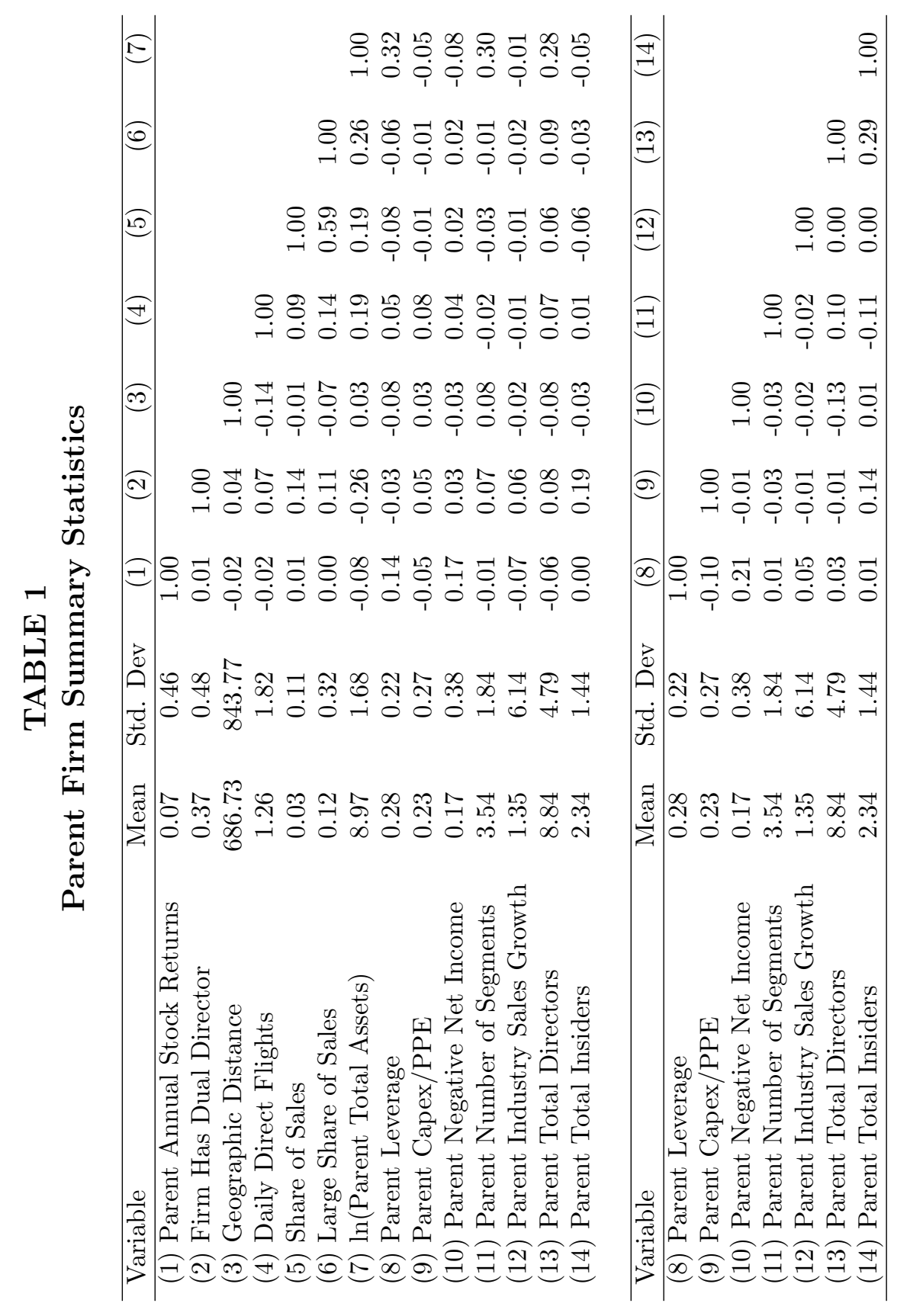




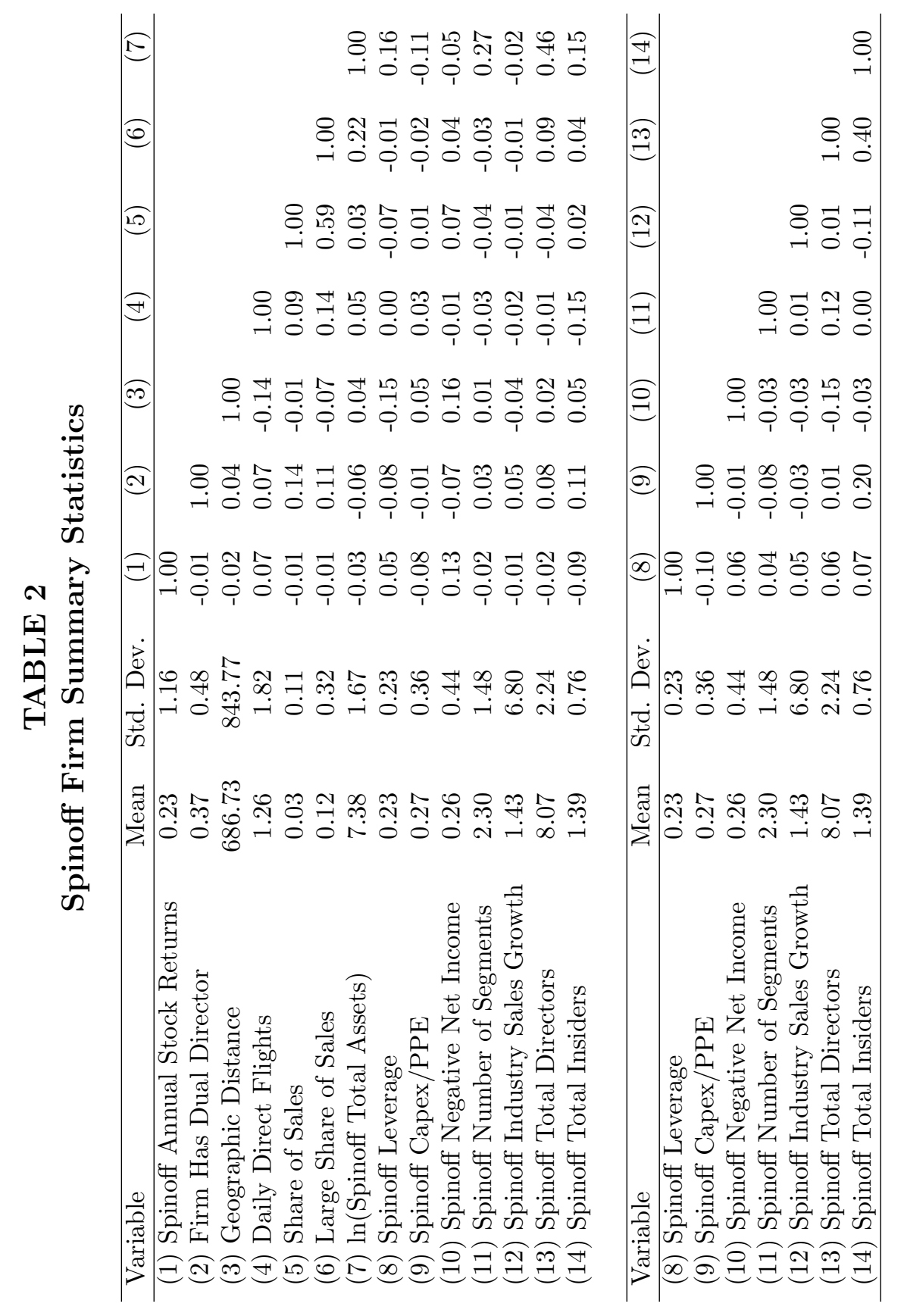


TABLE 3

Deal Fixed Effects Models, Value-Weighted Returns

\begin{tabular}{|c|c|c|c|c|}
\hline DV: Value-Weighted Returns & $(1)$ & $(2)$ & $(3)$ & $(4)$ \\
\hline \multirow{2}{*}{ Firm Has Dual Director } & & $0.31^{*}$ & $0.34^{*}$ & $0.36^{*}$ \\
\hline & & $(0.13)$ & $(0.13)$ & $(0.14)$ \\
\hline \multirow{2}{*}{ Firm Has DD $\times$ Share of Sales } & & & -0.62 & \\
\hline & & & $(0.80)$ & \\
\hline \multicolumn{2}{|l|}{ Firm Has DD $\times$ Large Share of Sales } & & & -0.35 \\
\hline \multirow[b]{2}{*}{$\ln ($ Parent Total Assets) } & & & & $(0.26)$ \\
\hline & $\begin{array}{c}-0.48^{*} \\
(0.23)\end{array}$ & $\begin{array}{c}-0.48+ \\
(0.25)\end{array}$ & $\begin{array}{c}-0.46+ \\
(0.25)\end{array}$ & $\begin{array}{c}-0.48+ \\
(0.24)\end{array}$ \\
\hline \multirow[t]{2}{*}{ Parent Leverage } & $4.12^{* *}$ & $4.24^{* *}$ & $4.30^{* *}$ & $4.30^{* *}$ \\
\hline & $(0.77)$ & $(0.78)$ & $(0.79)$ & $(0.78)$ \\
\hline \multirow[t]{2}{*}{ Parent Capex/PPE } & 0.01 & 0.01 & 0.01 & 0.01 \\
\hline & $(0.03)$ & $(0.03)$ & $(0.03)$ & $(0.03)$ \\
\hline \multirow[t]{2}{*}{ Parent Negative Net Income } & -0.08 & -0.09 & -0.09 & -0.09 \\
\hline & $(0.13)$ & $(0.12)$ & $(0.12)$ & $(0.12)$ \\
\hline \multirow[t]{2}{*}{ Parent Number of Segments } & $-0.15^{* *}$ & $-0.15^{* *}$ & $-0.15^{* *}$ & $-0.15^{* *}$ \\
\hline & $(0.05)$ & $(0.05)$ & $(0.05)$ & $(0.05)$ \\
\hline \multirow[t]{2}{*}{ Parent Industry Sales Growth } & $-0.01^{* *}$ & $-0.01^{* *}$ & $-0.01^{* *}$ & $-0.01^{* *}$ \\
\hline & $(0.00)$ & $(0.00)$ & $(0.00)$ & $(0.00)$ \\
\hline \multirow[t]{2}{*}{ Parent Total Directors } & 0.05 & 0.04 & 0.04 & 0.04 \\
\hline & $(0.05)$ & $(0.05)$ & $(0.05)$ & $(0.05)$ \\
\hline \multirow[t]{2}{*}{ Parent Total Insiders } & -0.16 & -0.15 & -0.14 & -0.15 \\
\hline & $(0.11)$ & $(0.11)$ & $(0.11)$ & $(0.11)$ \\
\hline \multirow[t]{2}{*}{$\ln$ (Spinoff Total Assets) } & -0.17 & -0.17 & -0.15 & -0.14 \\
\hline & $(0.15)$ & $(0.15)$ & $(0.15)$ & $(0.15)$ \\
\hline \multirow[t]{2}{*}{ Spinoff Leverage } & 0.41 & 0.50 & 0.50 & 0.52 \\
\hline & $(0.56)$ & $(0.54)$ & $(0.54)$ & $(0.54)$ \\
\hline \multirow[t]{2}{*}{ Spinoff Capex/PPE } & $-0.60^{*}$ & $-0.73^{*}$ & $-0.74^{*}$ & $-0.74^{*}$ \\
\hline & $(0.28)$ & $(0.29)$ & $(0.29)$ & $(0.29)$ \\
\hline \multirow[t]{2}{*}{ Spinoff Negative Net Income } & 0.08 & 0.10 & 0.10 & 0.10 \\
\hline & $(0.11)$ & $(0.11)$ & $(0.11)$ & $(0.11)$ \\
\hline \multirow[t]{2}{*}{ Spinoff Number of Segments } & 0.03 & 0.03 & 0.03 & 0.03 \\
\hline & $(0.05)$ & $(0.04)$ & $(0.04)$ & $(0.04)$ \\
\hline \multirow[t]{2}{*}{ Spinoff Industry Sales Growth } & -0.02 & -0.03 & -0.03 & -0.03 \\
\hline & $(0.05)$ & $(0.06)$ & $(0.06)$ & $(0.06)$ \\
\hline \multirow[t]{2}{*}{ Spinoff Total Directors } & 0.04 & 0.04 & 0.04 & 0.03 \\
\hline & $(0.04)$ & $(0.04)$ & $(0.04)$ & $(0.04)$ \\
\hline \multirow[t]{2}{*}{ Spinoff Total Insiders } & 0.09 & 0.13 & 0.13 & 0.13 \\
\hline & $(0.15)$ & $(0.16)$ & $(0.16)$ & $(0.16)$ \\
\hline Constant & $\begin{array}{l}4.45^{*} \\
(2.14)\end{array}$ & $\begin{array}{l}4.13+ \\
(2.25)\end{array}$ & $\begin{array}{c}3.94+ \\
(2.31)\end{array}$ & $\begin{array}{c}3.94+ \\
(2.25)\end{array}$ \\
\hline Deal Fixed Effects & Yes & Yes & Yes & Yes \\
\hline Year Fixed Effects & Yes & Yes & Yes & Yes \\
\hline Observations & 541 & 541 & 541 & 541 \\
\hline $\mathrm{R}^{2}$ & 0.61 & 0.62 & 0.62 & 0.62 \\
\hline \multicolumn{5}{|c|}{ All control variables are lagged by one year. } \\
\hline \multirow{2}{*}{\multicolumn{5}{|c|}{$\begin{array}{l}\text { Robust standard errors clustered by deal appear in parentheses. } \\
+\mathrm{p}<0.1\end{array}$}} \\
\hline & & & & \\
\hline $\begin{array}{l}+\mathrm{p}<0.1 \\
* \mathrm{p}<0.05\end{array}$ & & & & \\
\hline$* * 1$ & & & & \\
\hline
\end{tabular}




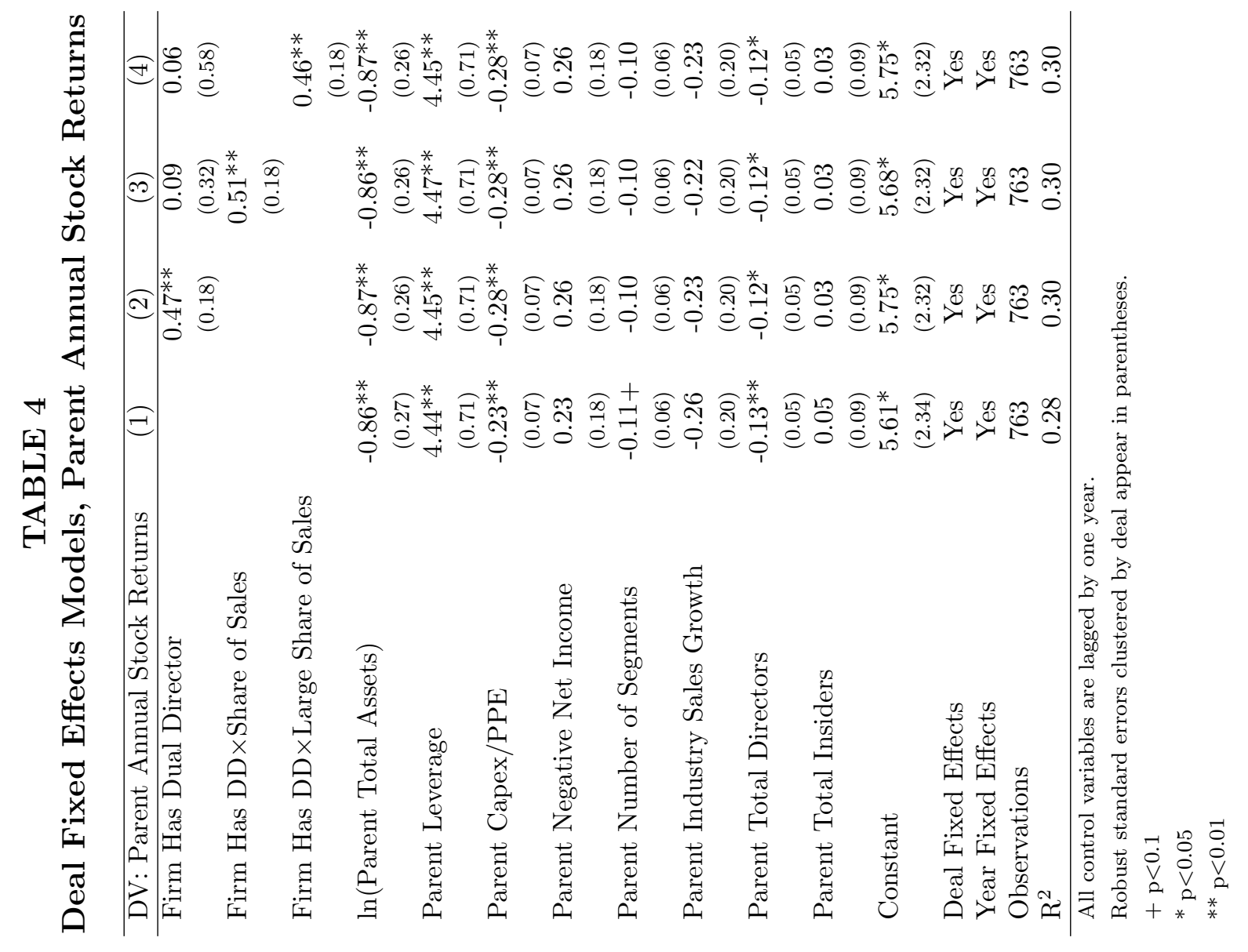




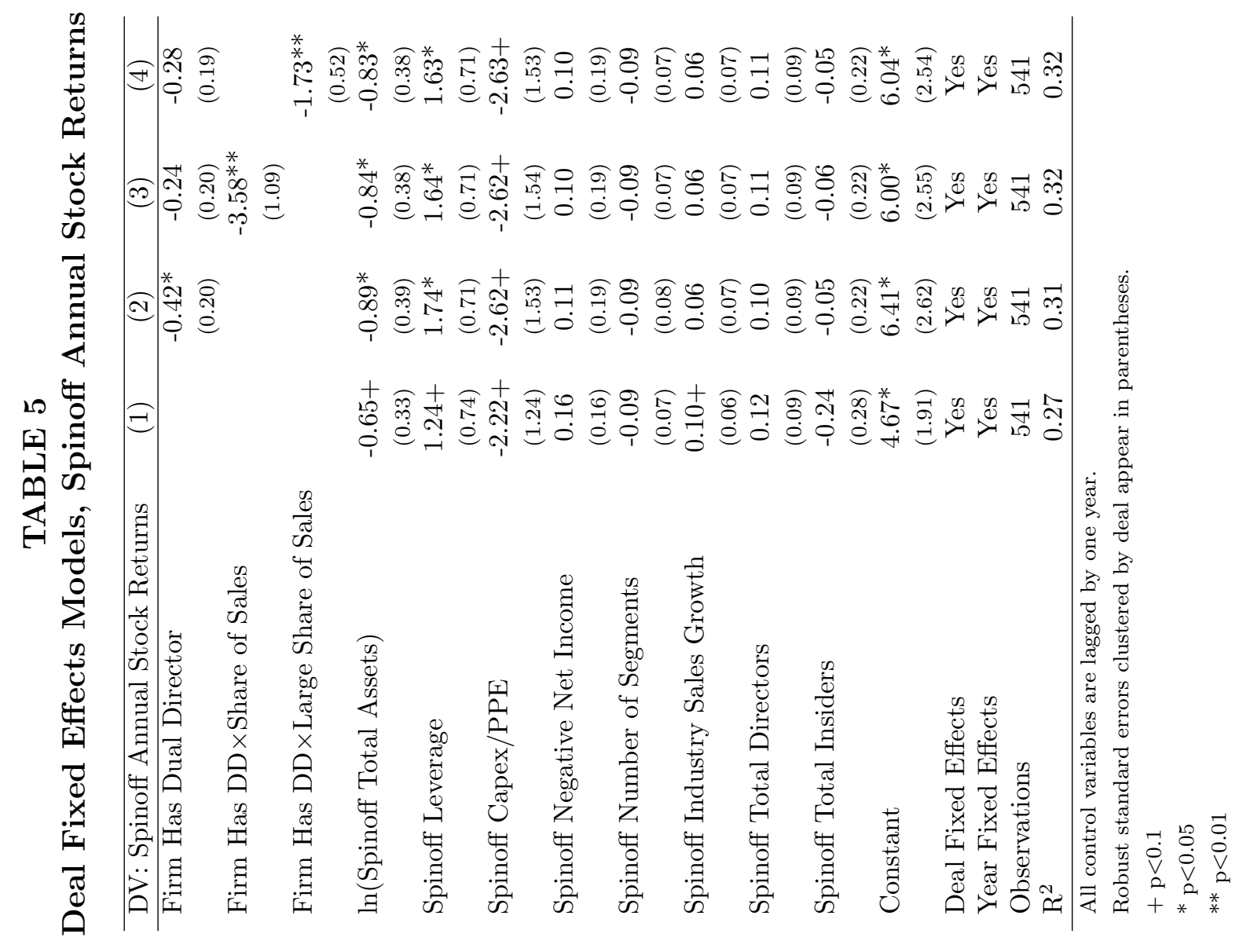


Figure 1

Interaction Between Firm Has Dual Director and Large Share of Sales in Predicting Parent Annual Stock Returns

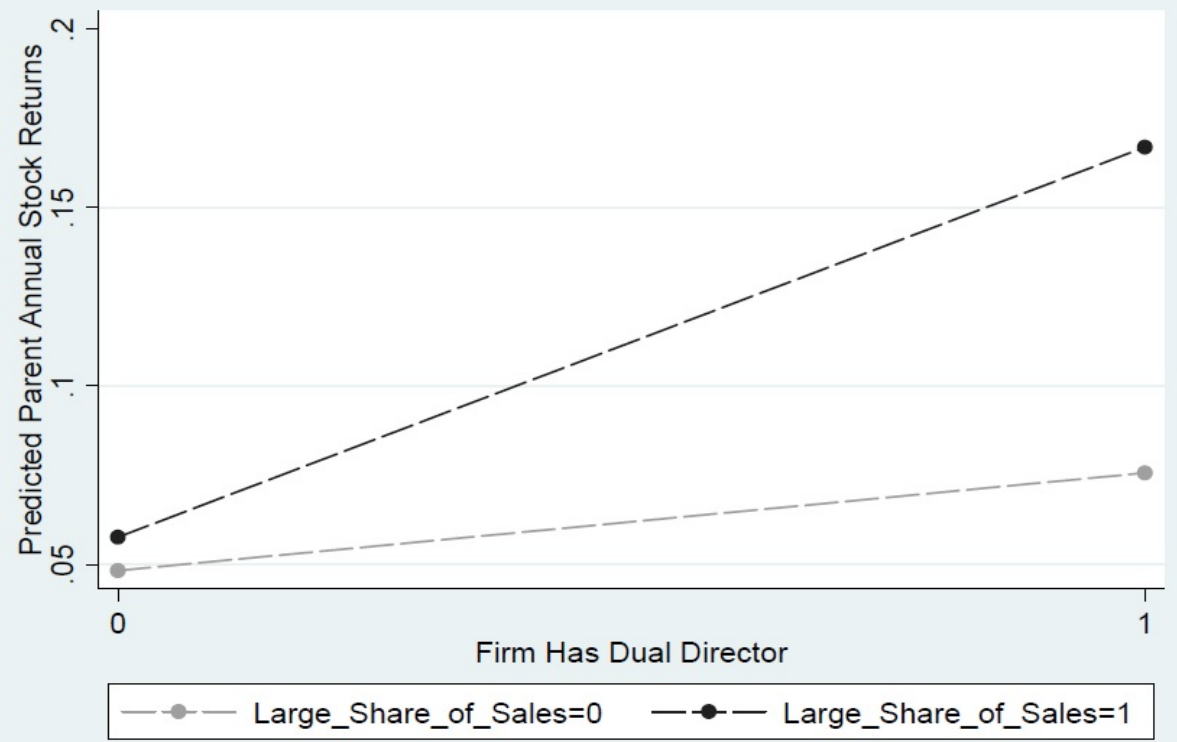

Figure 2

Interaction Between Firm Has Dual Director and Large Share of Sales in Predicting Spinoff Annual Stock Returns

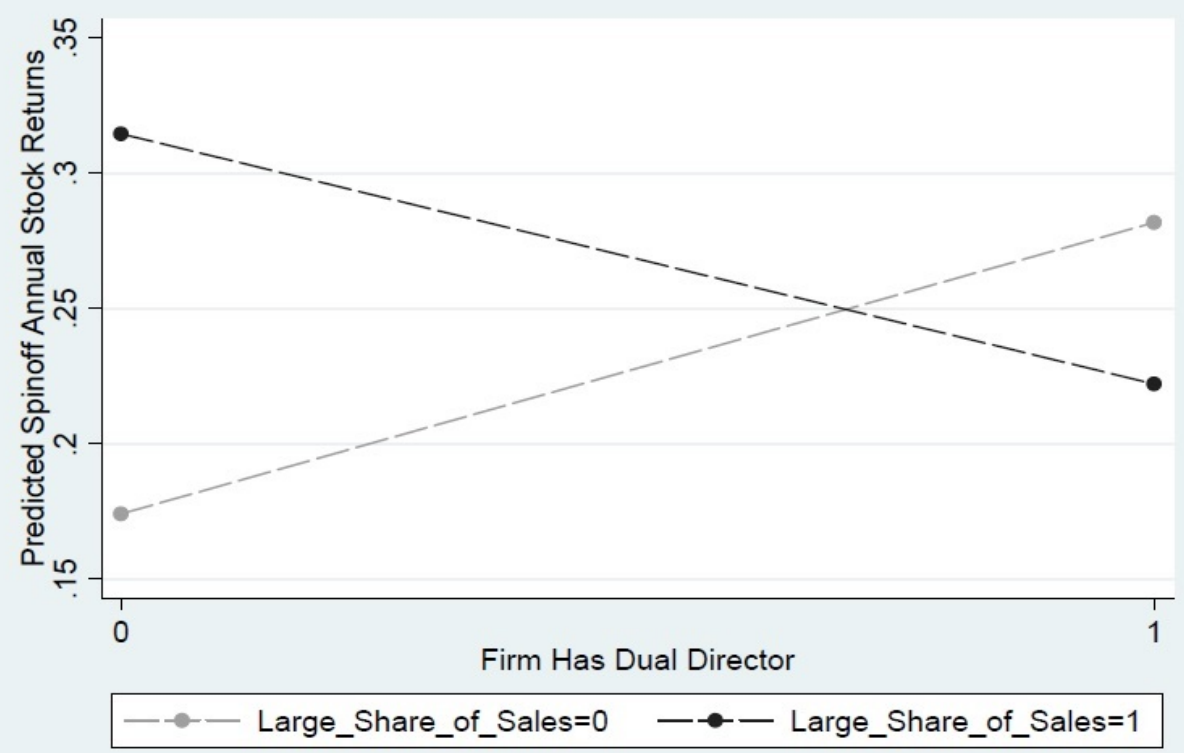


TABLE 6

Baseline Treatment Effects Models

\begin{tabular}{|c|c|c|c|c|}
\hline Dependent Variable: & (1) Firm Has DD & (2) Avg Returns & (3) Parent Returns & (4) Spinoff Returns \\
\hline Firm Has Dual Director & & $\begin{array}{c}0.59^{* *} \\
(0.23)\end{array}$ & $\begin{array}{c}0.99^{*} \\
(0.45)\end{array}$ & $\begin{array}{c}-1.67^{* *} \\
(0.53)\end{array}$ \\
\hline Geographic Distance & $\begin{array}{l}0.02^{*} \\
(0.01)\end{array}$ & & & \\
\hline Daily Direct Flights & $\begin{array}{l}0.14^{*} \\
(0.06)\end{array}$ & & & \\
\hline Large Share of Sales & $\begin{array}{l}0.43^{*} \\
(0.18)\end{array}$ & $\begin{array}{c}0.09 \\
(0.08)\end{array}$ & $\begin{array}{l}0.36+ \\
(0.19)\end{array}$ & $\begin{array}{l}-0.99^{*} \\
(0.40)\end{array}$ \\
\hline $\ln$ (Parent Total Assets) & $\begin{array}{c}-0.45^{* *} \\
(0.13)\end{array}$ & $\begin{array}{l}-0.11^{*} \\
(0.06)\end{array}$ & $\begin{array}{c}0.02 \\
(0.05)\end{array}$ & \\
\hline Parent Leverage & $\begin{array}{c}0.05 \\
(0.52)\end{array}$ & $\begin{array}{c}0.08 \\
(0.13)\end{array}$ & $\begin{array}{l}0.56^{*} \\
(0.27)\end{array}$ & \\
\hline Parent Capex/PPE & $\begin{array}{c}0.32 \\
(0.58)\end{array}$ & $\begin{array}{l}-0.01 \\
(0.05)\end{array}$ & $\begin{array}{l}-0.14 \\
(0.32)\end{array}$ & \\
\hline Parent Negative Net Income & $\begin{array}{c}0.23 \\
(0.26)\end{array}$ & $\begin{array}{l}0.16^{*} \\
(0.08)\end{array}$ & $\begin{array}{c}0.09 \\
(0.11)\end{array}$ & \\
\hline Parent Number of Segments & $\begin{array}{l}-0.05 \\
(0.06)\end{array}$ & $\begin{array}{l}-0.01 \\
(0.02)\end{array}$ & $\begin{array}{c}0.02 \\
(0.03)\end{array}$ & \\
\hline Parent Industry Sales Growth & $\begin{array}{c}0.07 \\
(0.17)\end{array}$ & $\begin{array}{l}-0.00 \\
(0.00)\end{array}$ & $\begin{array}{l}-0.09 \\
(0.07)\end{array}$ & \\
\hline Parent Total Directors & $\begin{array}{c}0.00 \\
(0.06)\end{array}$ & $\begin{array}{l}-0.00 \\
(0.01)\end{array}$ & $\begin{array}{l}-0.00 \\
(0.02)\end{array}$ & \\
\hline Parent Total Insiders & $\begin{array}{r}-0.16+ \\
(0.10)\end{array}$ & $\begin{array}{l}0.05+ \\
(0.03)\end{array}$ & $\begin{array}{c}0.00 \\
(0.04)\end{array}$ & \\
\hline $\ln$ (Spinoff Total Assets) & $\begin{array}{l}0.20^{*} \\
(0.10)\end{array}$ & $\begin{array}{l}0.06^{*} \\
(0.03)\end{array}$ & & $\begin{array}{c}0.02 \\
(0.12)\end{array}$ \\
\hline Spinoff Leverage & $\begin{array}{l}-0.47 \\
(0.58)\end{array}$ & $\begin{array}{c}0.06 \\
(0.13)\end{array}$ & & $\begin{array}{l}-0.60 \\
(0.56)\end{array}$ \\
\hline Spinoff Capex/PPE & $\begin{array}{c}0.03 \\
(0.63)\end{array}$ & $\begin{array}{l}-0.18 \\
(0.16)\end{array}$ & & $\begin{array}{r}-1.35+ \\
(0.84)\end{array}$ \\
\hline Spinoff Negative Net Income & $\begin{array}{c}-0.57^{*} \\
(0.25)\end{array}$ & $\begin{array}{l}-0.10 \\
(0.09)\end{array}$ & & $\begin{array}{c}0.27 \\
(0.27)\end{array}$ \\
\hline Spinoff Number of Segments & $\begin{array}{c}0.03 \\
(0.07)\end{array}$ & $\begin{array}{l}-0.00 \\
(0.02)\end{array}$ & & $\begin{array}{c}0.10 \\
(0.09)\end{array}$ \\
\hline Spinoff Industry Sales Growth & $\begin{array}{l}-0.06 \\
(0.18)\end{array}$ & $\begin{array}{c}0.01 \\
(0.04)\end{array}$ & & $\begin{array}{c}0.01 \\
(0.14)\end{array}$ \\
\hline Spinoff Total Directors & $\begin{array}{c}0.06 \\
(0.06)\end{array}$ & $\begin{array}{c}0.01 \\
(0.01)\end{array}$ & & $\begin{array}{l}0.11+ \\
(0.06)\end{array}$ \\
\hline Spinoff Total Insiders & $\begin{array}{l}-0.19 \\
(0.19)\end{array}$ & $\begin{array}{l}-0.06 \\
(0.04)\end{array}$ & & $\begin{array}{c}0.08 \\
(0.18)\end{array}$ \\
\hline Constant & $\begin{array}{l}1.75^{*} \\
(0.87)\end{array}$ & $\begin{array}{l}0.71+ \\
(0.43)\end{array}$ & $\begin{array}{l}-0.50 \\
(0.55)\end{array}$ & $\begin{array}{c}0.88 \\
(0.63)\end{array}$ \\
\hline Inverse Mills Ratio & & $\begin{array}{c}-0.37^{* *} \\
(0.12)\end{array}$ & $\begin{array}{c}-0.63^{* *} \\
(0.27)\end{array}$ & $\begin{array}{l}0.62^{* *} \\
(0.25)\end{array}$ \\
\hline
\end{tabular}

All control variables are lagged by one year.

$+\mathrm{p}<0.1$

$* \mathrm{p}<0.05$

$* * \mathrm{p}<0.01$ 


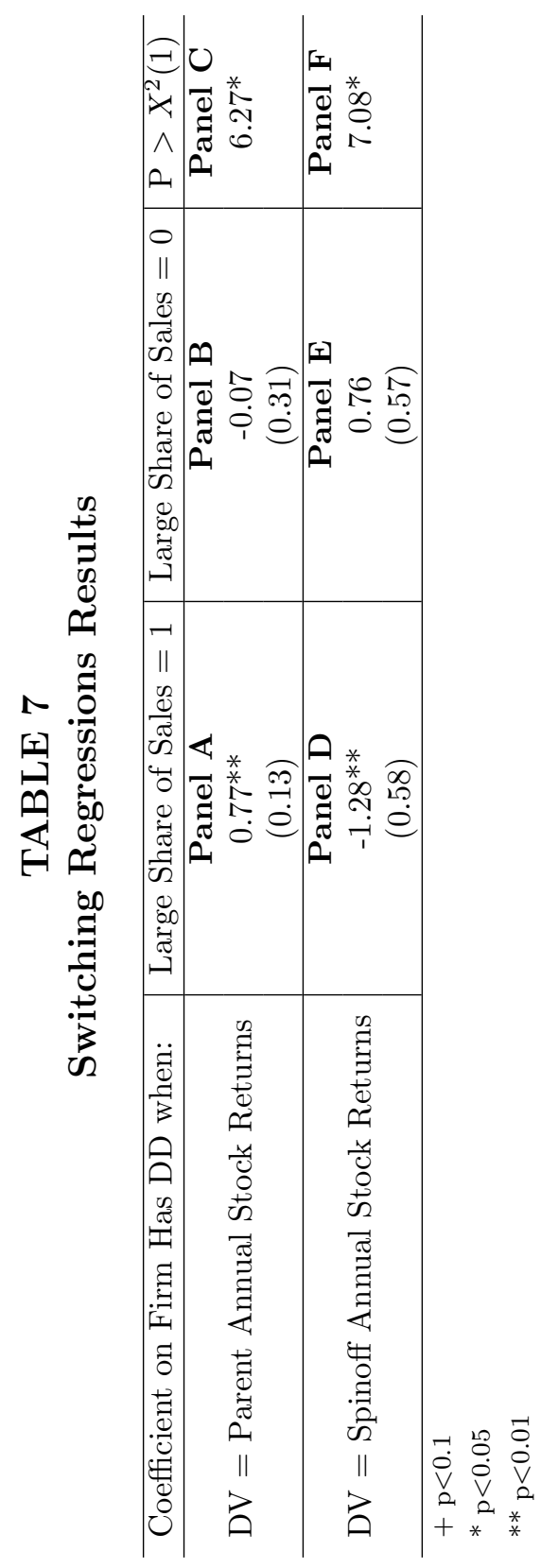

